\title{
Toll-Free Vanity Telephone Numbers: Structuring a Trademark Registration and Dispute Settlement Regime
}

\author{
Diana Lock $\dagger$
}

\section{TABLE OF CONTENTS}

Introduction

I. Evolution of the Toll-Free Telephone Number System ...............377

A. Development of the Market for Toll-Free Vanity

Telephone Numbers

B. The Analogy Between Toll-Free Vanity Telephone

Numbers and Internet Donıain Names

C. Further Examination of Problems with the FCC's Current

Toll-Free Number Registration System

1. Consumer Confusion: Equivalent and Complementary

$$
\text { Numbers. }
$$

2. Number Brokering

D. FCC and Industry Proposals to Reduce Consunier

Confusion and Resolve Disputes over Toll-Free Numbers .....389

1. Right of First Refusal ...............................................390

2. Industry Classifications ............................................391

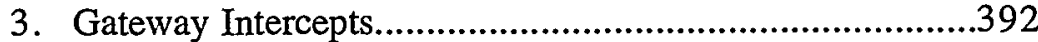

4. Partitioning.............................................................392

II. Analysis of Trademark Issues Concerning Toll-Free Vanity

Telephone Numbers ....................................................................393

A. State Common Law and Federal Trademark Protection..........393

1. Classification of Trademarks........................................394

2. Geographic Limits on Trademark Use ..........................395

3. Tradenıark Infringenient .........................................396

Copyright (c) 1999 California Law Review, Inc.

$\dagger \quad$ J.D. Candidate 1999, Boalt Hall School of Law, University of California, Berkeley; B.A., Weilesley College, 1993. I thank Professor Robert Merges, Jane Shay Wald, and all of my colleagues at the California Law Review and Berkeley Technology Law Journal, including Julie Jauregui Holloway, Shawna Parks, Justin Chang, Greg Jung, Heather Mewes, and Matt Kline. Finally, I want to thank my family, especially my sister, Cynthia Lock, who is both my friend and hero. I could not have survived law school without her unwavering support and strength. 
B. Case Law Trends in Disputes Involving Toll-Free Vanity

Telephone Numbers

1. Application of Traditional Trademark Analysis to Mnemonics 397

2. Passive Use Versus Active Use of Trademarks .................398

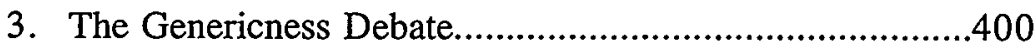

4. The Geographic Limitations Issue...................................402

III. Proposal for the Establishment of a New Registration and Dispute Settlement Policy for Toll-Free Telephone Numbers......403

A. Factors Contributing to the Need for a New Registration and Dispute Settlement Policy. 403

B. Registration and Dispute Settlement on the Internet ...............406

1. Criticisms of NSI's Current Policies...............................408

2. Proposals for Future Governance of the Internet.............409

a. IAHC's gTLD-MoU and CORE's CORE-MoU.........409

b. The Commerce Department's White Paper.

C. Proposed System for the Registration and Dispute Settlement of Toll-Free Numbers

1. Registration

2. Legal Standards

3. Dispute Resolution.

a. Opposition Proceedings

b. Cancellation Proceedings

c. Concurrent Use Proceedings

d. Interference Proceedings

e. Appeal Process 


\title{
Toll-Free Vanity Telephone Numbers: Structuring a Trademark Registration and Dispute Settlement Regime
}

\author{
Diana Lock
}

Last spring, the Federal Communications Commission responded to commercial and public demand for toll-free telephone numbers by adding the 877 prefix to the 800 and 888 service access codes. The release of a third, and future, toll-free prefix threatens to cause a flood of trademark litigation related to toll-free vanity telephone numbers. Telephone numbers are protectable as trademarks and often incorporate a company's trademark or trade name. As a result, vanity numbers often represent significant goodwill investments. The introduction of new service access codes will generate conflicts as holders of 800 vanity numbers, such as 800-GO-BEARS, challenge business competitors that reserve equivalent or similar numbers with different prefixes, such as 888-GO-BEARS or 877-GO-BARES. Likewise, the potential for cyberlaw litigation will increase as organizations create new Internet domain name registries, such as "store" or "flrm," that will compete with the "com" top level domain.

This Comment proposes that the FCC expand its first-come, firstserved registration policy for toll-free numbers by incorporating policies and proposals from the analogous context of Internet domain names. In addition, the author argues that the FCC should encourage businesses with conflicting toll-free vanity telephone numbers to utilize the Patent and Trademark Office's existing framework for trademark challenges and appeals. By adopting procedural mechanisms and legal rules that accommodate problems specific to the toll-free telephone number industry, the FCC will forestall a surge of trademark litigation involving conflicts between holders of toll-free vanity numbers.

\section{INTRODUCTION}

"Vanity," or mnemonic, phone numbers such as 800-WESTLAW or 888-MENS REA use the letters associated with the digits on telephone keypads to spell a word, name, or phrase. ${ }^{1}$ Such toll-free numbers

1. See In the Matter of Toll Free Service Access Codes, Notice of Proposed Rulemaking, CC Docket No. 95-155, 10 F.C.C.R. 13,692, I 35, at 13,701-02 (1995) [hereinafter Notice of Proposed Rulemaking] (defining a vanity number as "a telephone number for which the letters associated with 
have tremendous value to businesses because words are easier to remember than arbitrary strings of digits. ${ }^{2}$ Companies expect mnemonics to increase their business and reduce transaction costs for consumers, who can reach the companies' services with little thought or research. ${ }^{3}$ In addition, many businesses incorporate their trade name or trademark into the vanity number to make the number easier to memorize and to identify the business as the source of their goods or services. ${ }^{4}$ Vanity phone numbers, moreover, represent substantial company investments, both in the advertisement and promotion of the toll-free number, and the time, effort, and financial resources invested in a business' highly visible and recognizable trademark. ${ }^{5}$

The value of toll-free vanity phone numbers as marketing tools caused an explosion in the market for the numbers, and litigation has arisen with a corresponding frequency as businesses have sought to protect their investments. Telephone numbers are protectable as trademarks, and the use of confusingly similar numbers by competitors may constitute trademark infringement and unfair competition. ${ }^{6}$ In trademark infringement, unfair competition, and dilution actions, businesses with similar mnemonics have disputed the likelihood of consumer confusion between their respective toll-free numbers. The release of

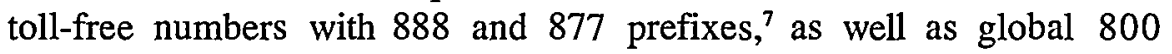

the number's digits on a telephone handset spell a name or word of value to the number holder," including "any numbers in which the holders have a particular interest, be it economic, commercial, or otherwise").

2. See Play Time, Inc. v. LDDS Metromedia Communications, Inc., 123 F.3d 23, 30-31 (1st Cir. 1997) (recognizing that a vanity number may have inherent market value); Allan Parachini, 1-800-Vanity: Like Personalized License Plates, Stylized Phone Numbers Suddenly Are Chic, L.A. TIMEs, Feb. 9, 1989, at I ('It's just a brute fact of life that we do remember words better than numbers .... A number, for most of us, is just an unrelated set of digits.").

3. See Dennis Hevesi, Now, Designer Phone Numbers, N.Y. Times, July 16, 1986, at B3 (quoting the office manager of a beeper company with the number 1-800-BEEPERS as saying, "We get a lot of phone calls from people who just know they're looking for a beeper company."). In contrast, some consumers complain about difficulties in finding the appropriate letters on the phone, and others are poor spellers. See id.; Kevin Maney, Dial 1-800-I'M-RICH, USA ToDAY, Apr. 28, 1994, at B2 ("Much of the general public can't spell. People have attempted to get AT\&T by calling 1-800-OPERATER," instead of 1-800-OPERATOR.); Parachini, supra note 2, at 1 ("TT]he advantage of a vanity phone number that can be remembered easily may be lost as the caller stares in frustration at the keypad trying to find the buttons with the right letters.").

4. See Dial-A-Mattress Franchise Corp. v. Page, 880 F.2d 675, 678 (2d Cir. 1989).

5. See Edmund L. Andrews, A Square-Off for a Toll-Free Prize, N.Y. TimEs, Apr. 29, 1993, at D1; Gautam Naik, Not That Many 800 Phone Numbers Are Free Anymore, FCC to Add New Prefix, 888, For Toll-Free Calls, WALL ST. J., Aug. 17, 1995, at B4 ("Toll-free service is huge business, bringing $\$ 10$ billion in annual revenue to long-distance companies. AT\&T said that over $40 \%$ of all calls placed on its network are 800 calls.").

6. See Dial-A-Mattress, 880 F.2d at 678 . This Comment will focus on trademark infringement issues.

7. See Mike Mills, 888-Prefix Toll-Free Lines Begin: Businesses Worry about Losing Cachet of 800 'Vanity' Numbers, Wash. Post, Mar. 1, 1996, at F1; Gregory J. Wilcox, Third Area Code Set to Debut for Toll-Free Numbers, L.A. Dally News, Apr. 4, 1998, at B1; infra Section I.A. 
numbers, ${ }^{8}$ promises to foster additional litigation as holders of 800 numbers challenge busmesses with equivalent numbers, but new, different prefixes. Moreover, the recent increase in the black market sale of toll-free numbers, a practice called "number brokering," may presage a telephonic version of Internet cyber-squatters. ${ }^{10}$ In other words, individuals may attempt to extort money by reserving and reselling vanity numbers back to the businesses that have already invested enormous amounts of time and money in developing the trademark. ${ }^{11}$

Courts have attempted to apply a traditional likelihood of confusion test to disputes involving both the Internet and vanity numbers. However, the test falls short of solving all issues in the context of tollfree vanity numbers. To prove infringement, the holder of a vanity number must first establish a protectable trademark, and then show, under a multi-factor test, a likelihood of confusion between the protected and allegedly infringing marks. ${ }^{12}$ However, legal analysis of telephone mnemonics must not only apply traditional trademark law, but also accommodate problems specific to the telecommunications industry. ${ }^{13}$ For example, current technology dictates that telephone numbers are unique; only a finite number of vanity numbers are therefore available. The limited supply of toll-free numbers and their exclusive nature contributes to their value and leads to disputes between multiple parties fightimg for use of the same number. In contrast to traditional trademark law, which allows more than one business in non-competing industries to own nonexclusive trademark rights in a name, only one company can hold a single telephone number. ${ }^{14}$

8. See Jube Shiver, Jr. \& Karen Kaplan, Carriers Plan Toll-Free Global Calls, L.A. TimEs, Feb. 7, 1997, at Al; infra Section I.A.

9. See Karen E. Klein, Small Talk: Small Business $Q \& A$, L.A. Trmes, Oct. 1, 1997, at D6; Maney, supra note 3, at B2; infra Section I.C.2.

10. See Panavision Int'l, L.P. v. Toeppen, 945 F. Supp. 1296, 1300 (C.D. Cal. 1996); Intermatic, Inc. v. Toeppen, 947 F. Supp. 1227, 1233 (N.D. Ill. 1996) ("[Cyber-squatters] attempt to profit from the Internet by reserving and later reselling or licensing domain names back to the companies that spent millions of dollars developing the goodwill of the trademark."); infra note 93.

11. See Christa Degnan, 800-Mania is Gripping the Nation, 15 Mass Hrgh TECH 25:1 (1997).

12. See, e.g., Frisch's Restaurants, Inc. v. Elby's Big Boy of Steubenville, Inc., 670 F.2d 642, 648 (6th Cir. 1982); AMF, Inc. v. Sleekcraft Boats, 599 F.2d 341, 348-49 (9th Cir. 1979); Scott Paper Co. v. Scott's Liquid Gold, Inc., 589 F.2d 1225, 1229 (3d Cir. 1978); Polaroid Corp. v. Polarad Elecs. Corp., 287 F.2d 492, 495 (2d Cir. 1961); infra Section II.A.3.

13. The contours of the Internet pose analogous problems for domain names. See Lockheed Martin, Corp. v. Network Solutions, Inc., 985 F. Supp. 949, 958 (C.D. Cal. 1997) (likeming domain names and vanity phone numbers because both have non-trademark, technical purposes and trademark-related source identification functions).

14. See id. But see Murrin v. Midco Communications, Inc., 726 F. Supp. 1195, 1201 (D. Minn. 1989) (allowing an applicant who acquired common law rights in the phrase "Dial LAWYERS" from his use of the number 212-LAWYERS to operate 800-LAWYERS in the New York City metropolitan area, but enjoining him from any use that would infringe the rights of the holder of an identical incontestable service mark). 
Moreover, the Federal Communications Commission (FCC), which establishes rules governing toll-free telephone numbers, considers telephone numbers to be "a scarce and valuable national public resource," 15 in which neither carriers nor users may maintain ownership interests. Although many holders of toll-free numbers invest large amounts of capital in the numbers, businesses cannot claim the digits underlying mnemonics as property. ${ }^{16}$ Instead, companies assert intellectual property rights in the mnemonic itself. ${ }^{17}$ The FCC strives to "balance goodwill and the holder's interest in a vanity 800 number against the need to manage a limited resource."18

In this Comment, I propose that the FCC adopt provisions for assignment and dispute settlement that specifically accommodate trademark issues involving toll-free vanity phone numbers. The proposed framework embraces policies and proposals for registration found in the analogous context of Internet domain names. Also, I recomniend that the FCC encourage parties to use the Patent and Trademark Office's (PTO's) existing trademark challenge and appeal procedures for dispute settlement.

The framework consists of three specific proposals. First, the FCC should expand the screening capabilities of present databases. This will enable applicants to search for available toll-free numbers and for potential conflicts with numbers that are confusingly similar or that have different prefixes but are otherwise identical. Second, in addition to carriers' current policy of assigning numbers on a first-come, first-served basis, ${ }^{19}$ the FCC should require applicants to certify that their use of a particular vanity number does not infringe the intellectual property rights of third parties and will not be used for unlawful purposes. ${ }^{20}$

15. In the Matter of Toll Free Service Access Codes, Second Report and Order and Furthcr Notice of Proposed Rulemaking, CC Docket No. 95-155, F.C.C. No. 97-123, 11,162, I 22, at 11,178 (1997) [hereinafter Second Report and Order].

16. See Burris v. S. Cent. Bell Tel. Co., 540 F. Supp. 905, 908 (S.D. Miss. 1982) ("The subscriber has no property right to the telephone number or any other call number designation associated with services furnished by the [telephone] company...."); Notice of Proposed Rulemaking, supra note 1, 99 36, 38. But see Jon Van, A Number You Can Call Your Own, CH1. TR13., Mar. 30, 1998, at 1 (suggesting that local and, eventually, national portability of personal phone numbers inplies that "[c]ustomers, not the phone company, will own their phone numbers ...").

17. See Notice of Proposed Rulemaking, supra note $1,939$.

18. Id. I 35.

19. See Jennifer Oldham, Toll-Free Numbers Crunch Brings Snafus, Calls for Change, L.A. TIMES, Nov. 10, 1997, at D4 (noting that despite the FCC's suppression of 375,000 numbers with an 888 prefix, carriers will release all numbers with an 877 prefix on a first-come, first-scrved basis); infra Section I.C.

20. Cf. Gayle Weiswasser, Domain Names, the Internet, and Trademarks: Infringement in Cyberspace, 13 SANTA Clara Computer \& High TECH. L.J. 137, 159 (1997) (outlining the registration and dispute policies for Internet domain names); Interim Policy Oversight Committee, Substantive Guidelines Concerning Administrative Domain Name Challenge Panels (visited May 23, 1997) <http://gtld-mou.org/docs/racps.htm> [hereinafter Substantive Guidelines]. 
Finally, subscribers should have the ability to challenge the registration of mnemonics that are identical or confusingly similar to established trademarks by initiating an opposition, cancellation, concurrent use, or interference proceeding at the PTO, and by following the PTO's procedures to appeal the decision in those proceedings. ${ }^{21}$

Part I of this Comment describes the development of the market for toll-free vanity numbers; draws an analogy between toll-free vanity numbers and Internet domain names; discusses the probleins caused by the FCC's first-come, first-served policy for registration; and, finally, summarizes FCC and industry proposals to resolve those concerns. Part II explains the state of the law regarding telephone mnemonics and discusses problems of legal analysis. Part III outlines the current and proposed registration and dispute settlement policies for domain names. It also proposes that the FCC address trademark issues involving vanity numbers by adopting a registration system analogous to those used and proposed for domain naines and by utilizing the PTO's trademark challenge and appeal procedures for dispute settleinent.

\section{Evolution of the Toll-Free Telephone Number System}

\section{A. Development of the Market for Toll-Free Vanity Telephone Numbers}

In recent years, the demand for toll-free telephone numbers has skyrocketed. AT\&T released the first 800 toll-free numbers for large businesses in $1967,{ }^{22}$ and coinpetitors followed after the breakup of the Bell System in $1984 . .^{23}$ The popularity of vanity numbers did not gain moinentum until 1986, however, when the widespread use of vanity license plates in California prompted Pacific Bell to allow inatching phone numbers. ${ }^{24}$ At the same time, changes in technology enabled companies to use one number on a nationwide basis. ${ }^{25}$ In 1993, the FCC ordered phone companies to make 800 numbers portable. Portability allows businesses to take their toll-free numbers with them when they

21. See Patent and Trademark Office, U.S. Dep't of Commerce, Trademark Trial and Appeal Board Manual of Procedure § 102.02, 901.01 (1st ed. 1995) [hereinafter TBMP]; infra Section III.C.

22. See Second Report and Order, supra note 15, I 4 (noting that 800 service features, such as payment of the call by the recipient and uniformity of the number regardless of geographic location, "proved so valuable to businesses that the service flourished domestically and internationally"); Elizabeth A. Horky, Note, 1-800-1-AM-VAIN: Should Telephone Mnemonics Be Protected as Trademarks?, 3 J. INTELL. PROP. L. 213, 227-30 (1995) (summarizing the history of toll-free numbers in the telecommunications industry).

23. See Mike Mills, Popularity Takes Toll on 800 Numbers: As Supply Dwindles, Phone Companies Turn to New 888 Prefix, WASH. Post, July 5, 1995, at A1.

24. See Hevesi, supra note 3 , at B3.

25. See Horky, supra note 22 , at 228 n.70. 
switch carriers. ${ }^{26}$ With the advent of portability, the market for toll-free telephone numbers exploded. Today, over 90 percent of the 7.78 million possible combinations of 800 numbers are no longer available. About 6.3 million are working phone numbers, and the remainder are reserved, assigned, disconnected, or otherwise unavailable. ${ }^{27}$

In March of 1996, the diminishing supply of 800 numbers precipitated the release of the toll-free 888 service access code (SAC) by long-distance carriers. ${ }^{28}$ The available numbers with an $888 \mathrm{SAC}$, in turn, quickly disappeared. Businesses and individuals snatched up approximately 400,000 numbers per month, causing the eight million available 888 numbers to become unavailable within two years. ${ }^{29}$ On April 5, 1998, the 877 SAC joined the pool of toll-free numbers. Due to the high demand for toll-free numbers, 877 numbers will remain available for less than two years before carriers introduce the 866 prefix, followed by the $855 \mathrm{SAC}$, and so on, to meet demand. ${ }^{30}$

The release of the 888 and 877 numbers produced three principal problems that remain unresolved. First, businesses with 800 vanity numbers fear that competitors will reserve identical mnemonics in the new toll-free prefixes, and thereby cause consumer confusion and dilution of their trademarks. ${ }^{31}$ To prevent others from exploiting consumer confusion and free-riding on the goodwill established by their investments in the advertisement and promotion of 800 numbers, many businesses with vanity 800 numbers claimed a proprietary interest in corresponding 800 numbers and lobbied for a right of first refusal. ${ }^{32}$ The FCC responded to industry concerns by suppressing the use of 374,199 numbers with the 888 prefix pending a decision about treatment of corresponding numbers. ${ }^{33}$ The $F C C$ recently conferred a right of first refusal on businesses for the set-aside vanity 888 numbers, but the agency conditioned the right on the active investment, advertisement, and use of

26. See Andrews, supra note 5, at D1; Mills supra note 23, at A1.

27. See Mills, supra note 23, at A1.

28. See Mills, supra note 7, at F1.

29. See Wilcox, supra note 7 , at $\mathrm{B} 1$.

30. See Pradnya Joshi, '877' To Join Toll-Free Codes, Demand Prompted Approval by FCC, NewSDAY, Apr. 2, 1998, at A69; Mills, supra note 7, at F1.

31. See Oldham, supra note 19 , at $\mathrm{D} 4$.

32. See id.

33. See In the Matter of Toll-Free Access Codes, Fourth Report and Order and Memorandum Opinion and Order, CC Docket No. 95-155, F.C.C. No. 98-48, 9058, J 9, at 9063-64 (1998) [hereinafter Fourth Report and Ordcr]; Oldham, supra note 19, at D4. The FCC only allowcd businesses to reserve 888 numbers before February 1, 1996, and some carriers failed to inform 800 vanity number holders, especially small businesses, of the FCC deadline. See In the Matter of Service Access Codes, Common Carrier Bureau, Report and Order, 11 F.C.C.R. 2496, 9J 15, 17 at 2499 (1996) [hereinafter First Report and Order]. Mills, supra note 7, at FI. The FCC's Common Carrier Bureau later allowed omitted subscribers to request protection for their equivalent numbers. See Fourth Report and Order, supra, I 35. 
the numbers. ${ }^{34}$ This prevents a business from hoarding a set-aside number merely to prevent use by competitors. ${ }^{35}$ Contrary to the FCC response to the $888 \mathrm{SAC}$, carriers will release all future toll-free numbers, including the 877 and $866 \mathrm{SACs}$, on a first-come, first-served basis. ${ }^{36}$ As a result, businesses that use 800 vanity numbers and are unable to reserve equivalent numbers in the 877 and 866 SACs, will remain vulnerable to a threat of consumer confusion, free riding, and black-market brokers.

Second, a practical problem arose from the release of the 888 SAC that reflected the existence of actual consumer confusion. Businesses with 800 vanity numbers received a flood of wrong number calls. Because carriers bill the holders of toll-free numbers on a per-minute basis for incoming calls, in addition to a flat monthly fee, the calls were costly mistakes. ${ }^{37}$

Finally, adding to the potential for consumer confusion, global tollfree numbers became available for use in the spring of $1998{ }^{38}$ The numbers function in the United States, Canada, Australia, Hong Kong, and ten European countries. Japan, Singapore, and some developing nations have also expressed interest $\mathrm{m}$ participating in the international system. ${ }^{39}$ The United Nation's International Telecommunications Union (ITU) began assigning the eight-digit numbers on a first-come, firstserved basis in February of 1997. The numbers are assigned through long-distance carriers, and have an 800 prefix along with a three digit country code.$^{40}$ Within the first year that the ITU accepted applications, the organization received 17,000 applications, over two thousand of which conflicted. Sixty-five companies requested the number 888-8888 alone. ${ }^{41}$ Many American businesses that use domestic vanity numbers have also applied for global mnemonics. ${ }^{42}$

34. See Fourth Report and Order, supra note 33, I 30.

35. See id.

36. See id. I 39; Oldham, supra note 19 , at D4.

37. See Second Report and Order, supra note 15, If 74 ("[T]he subscriber receiving the misdialed calls must either bear the cost of those calls or track them so that it may receive credit from its toll free service provider."); Oldham, supra note 19, at D4.

38. See Shiver \& Kaplan, supra note 8, at A1.

39. See id.

40. See Mark Landler, The Next Thing to Go Global Will Be Toll-Free Numbers, N.Y. Times, June 17,1996 , at D5.

41. See Tom Weidlich, You Can't Come in and Play: ITU Curtails Public Access to On-Line Toll-Free Number Database, 9 Cowles Bus. Media 19 (1997).

42. See Shiver \& Kaplan, supra note 8, at A1. 


\section{B. The Analogy Between Toll-Free Vanity Telephone Numbers and Internet Domain Names}

The nature of toll-free vanity telephone numbers presents a strong analogy to Internet domain names, and supports the adoption of a tollfree number registration system modeled after the registration process for Internet domain names. First, vanity toll-free numbers and domain names have analogous structures because both correspond to unique numerical designations. ${ }^{43}$ Just as each vanity number incorporates a word, name, or phrase associated with a single telephone number, every Internet user has an Internet Protocol Address (IP Address), such as 169.229.97.110, that corresponds to a domain name. ${ }^{44}$ In both contexts, mnemonics are simpler to use and remember than a random string of digits. Also, both vanity toll-free numbers and domain names consist of core mnemonics with either differing toll-free prefixes or different top level domains (TLDs). A TLD, such as ".com" for commercial entities or ".net" for computer sites or networks, indicates the purpose or function of an organization, ${ }^{45}$ and is analogous to a toll-free prefix. A second level domain (SLD), such as "calbear," which identifies the registrant of the domain name, ${ }^{46}$ is analogous to the final, core seven digits of a telephone. Thus, a company that uses the domain name "calbear.com" may want to challenge a competitor who reserves "calbear.net;" similarly, a business using the vanity number 800CALBEAR may claim infringement if a competitor advertises 888CALBEAR.

Second, both vanity numbers and domain names constitute valuable business assets and reflect a company's goodwill and investment in advertising and promotion because businesses often incorporate a trade name or trademark into their vanity number or domain name. ${ }^{47}$ In both industries, mnemonics serve a source-identification function and make the telephone number or web site easier to reach and to remember. For example, people frequently guess Internet addresses, so an easily

43. See Lockheed Martin, Corp. v. Network Solutions, Inc., 985 F. Supp. 949, 952 (C.D. Cal. 1997) (describing the numbering system and structure of Internet domain names).

44. See id.

45. See Weiswasser, supra note 20 , at 146 (detailing the strncture of domain names).

46. See id.

47. See MTV Networks v. Curry, 867 F. Supp. 202, 203-04 n.2 (S.D.N.Y. 1994) ("Internet domain names are similar to telephone number mnemonics, but they are of greater importance, since thcre is no satisfactory Internet equivalent to a telephone company white pages or directory assistance, and domain names can often be guessed. A domain name inirroring a corporate namc may be a valuable corporate asset, as it facilitates communication with a customer base."). Goodwill is "the intangible value of a business" that "reflects the basic human propensity to continue doing business with a seller who has offered goods and services that the customer likes and has found adequate to fulfill his needs." $1 \mathrm{~J}$. ThOMAS MCCARTHY, MCCARTHY ON TRAdEMARKS AND UNFalR COMPETITION § 2:17 (4th ed. 1998). 
identifiable domain name may reduce transaction costs for users, who will spend less time and energy accessing the wrong web sites. ${ }^{48}$

Third, the unique nature of domain names and toll-free telephone numbers dictates that only a restricted quantity of both exists. The inherently exclusive nature of toll-free numbers and domain names generates conflicts between multiple users with equally legitimate claims. Businesses in non-competing industries can lawfully retain traditional trademark rights in the same mark, but only one entity can use a domain name or vanity number that incorporates that mark. ${ }^{49}$ The problem of multiple legitimate users becomes exacerbated on the Internet because many businesses use acronyms for their domain name mstead of their full trade name or trademark. Acronyms are popular because domain names are limited to twenty-six digits or letters, and fewer characters are easier to remember. ${ }^{50}$ Unfortunately, this trend increases the number of businesses with different trade names or trademarks but legitimate claims to the same acronym..$^{51}$ Similarly, although every telephone number is unique, each can generate a variety of mnemonics because most digits on a telephone keypad correspond to three letters. As a result, numerous companies with different trade names or trademarks may seek to use the same vanity number.

Fourth, just as the introduction of new prefixes will generate conflicts in the toll-free numbers context, the potential for cyberlaw litigation will increase as organizations establish new, competing registries for commercial users. Domain name litigation primarily has involved trademark disputes over identical marks, not similar or complementary ones, because most businesses reserve domain names in the ".com" TLD alone..$^{52}$ However, the expiration of the contract to assign domain names between the government and Network Solutions, Inc. (NSI) may lead to the establishment of a more competitive system of assigning

48. See David J. Loundy, A Primer on Trademark Law and Internet Addresses, 15 J. Marshall J. COMPUTER \& INFO. L. 465, 468 (1997) (explaining that domain names derive value from ease of location on the Internet); supra note 3.

49. See, e.g., Juno Online Servs., L.P. v. Juno Lighting, Inc., 979 F. Supp. 684 (N.D. II. 1997) (involving a challenge by an on-line provider of e-mail which had registered "juno.com" to the registration by a manufacturer and retailer of recessed and track lighting).

50. See, e.g., Stacy B. Sterling, Comment, New Age Bandits in Cyberspace: Domain Names Held Hostage on the Internet, 17 Loy. LA. ENT. L.J. 733, 736 (1997) ("For example, 'American Telephone and Telegraph' and 'Al's Tumips and Tomatoes' would both compete for 'at\&t.com."); Weiswasser, supra note 20, at 170 (noting that Internet users are encouraged to use fewer than twenty-four characters in their domain naines).

51. See Weiswasser, supra note 20 , at 170.

52. However, identical marks may be used with different country codes. See Johnathan E. Moskin, Postcards from the Internet: Domain Name Infringement, N.Y. L.J., Mar. 10, 1997, at S6. 
domain names. ${ }^{53}$ NSI recently agreed to allow competing companies to register domain names and have access to its technical data. ${ }^{54}$ The International Ad Hoc Committee (IAHC) and the European-based International Council of Registrars (CORE) have proposed the immediate addition of up to seven new registries from four global regions, and the further addition of twenty to thirty more registrars each year. ${ }^{55}$ Just as companies with 800 vanity numbers may increasingly challenge competitors using identical numbers with different prefixes, the release of new TLDs, such as ".firm," “.store," ".web," ".arts," “.rec," ".info," and ".nom," may generate litigation as businesses with domain names in the "com" TLD allege trademark infringement by competitors who reserve equivalent or complementary domain names in different registries. ${ }^{57}$

Finally, like toll-free telephone numbers, the Internet is "a new medium, [where] courts must still apply traditional trademark law, while also considering the policy implications." 58 Thus, courts determine trademark infringement involving domain names by applying the same

53. NSI's contract expired on September 30, 1998, but the Commerce Department granted a one week extension. See Matt Beer, Web Domain Overseer Gets 7-Day Reprieve, S.F. ExAMINER, Sept. 30, 1998, at B1.

54. See John Simons \& Glenn R. Simpson, U.S., Network Solutions Reach Accord to Open Web Addressing to Competition, WALL ST. J., Oct. 6, 1998, at B8.

55. See Sheldon H. Klein, New Attempt at Domain Name Accord: Numerous Proposals Try to Balance Rights of Domain-Name and Trademark Holders, NAT'L L.J., May 5, 1997, at B11 (explaiming the IAHC proposal for future governance of the domain name system). The Department of Commerce proposed the addition of up to five new registries in its so-called Green Paper, which outlines recommendations for future technical management of Internet domain names, but has since backed away from suggesting a specific number of new generic top level domain names (gTLDs). See Sheldon H. Klein \& Anthony V. Lupo, 'White Paper' Leaves Some Domain Gray: Latest Policy Statement on Privatization of the Internet Domain-Name System Doesn't Resolve All Trademark, Governance Issues, NAT'L L.J., June 29, 1998, at B7.

56. See Jennifer B. Lucas, IAHC Announces New Top-Level Domains; Recommends New Challenge Procedures, 2 BNA's ELEC. INFo. PoL'Y \& L. REP. 152-53 (Feb. 7, 1997) (listing the seven new gTLDs proposed by the IAHC); Heather N. Mewes, Note, Memorandum of Understanding on the Generic Top-Level Domain Name Space of the Internet Domain Name System, 13 BERKeLEY TECH. L.J. 235, 245 (1998) (noting that many large businesses, such as NBC, may fall into more than one TLD, such as ".firm," “.rec," and ".info").

57. In addition, businesses may soon challenge the use of similar but non-identical domain names more regularly. For example, in a case that eventually settled, Wired magazine, which covers computer and Internet topics, objected to the use of "wire.net" by Wire, a computer network for women on the Internet. Wired alleged that Wire's domain name was confusingly similar to its own "wired.com." The network agreed to change its domain name to "wwire.net." See Gary W. Hamilton, Trademarks on the Internet: Confusion, Collusion or Dilution?, 4 TEx. INTELL. Prop. L.J. 1, 5-6 (1995) (citing Elizabeth Weise, Feud Highlights Growing Importance of Internet, B. GLOBE, Feb. 22, 1994, at 42). See also Weiswasser, supra note 20, at 176 ("[C]ritics charge that the current domain name registration system does not adequately address the problem that occurs when companies register homonyms, such as 'codak.com' and 'kodak.com,' or when companies register names that are very similar to existing names, such as 'xeroxx.com."').

58. Intermatic, Inc. v. Toeppen, 947 F. Supp. 1227, 1228 (N.D. Ill. 1996). 
multi-factor tests for likelihood of confusion..$^{59}$ Likewise, courts utilize trademark dilution law when identical or similar domain names incorporate famous trademarks. ${ }^{60}$

\section{Further Examination of Problems with the FCC's Current Toll-Free Number Registration System}

The analogy between vanity telephone numbers and Internet domain names extends to the problems underlying the first-come, firstserved registration process followed by both NSI and the FCC. ${ }^{61}$ Supporters of the FCC's first-come, first-served policy describe it as the most equitable, "simple, efficient, and inexpensive [method] to administer." ${ }^{62}$ Under the current system, a busmess acquires a toll-free phone number by contacting a telecommunications company that offers tollfree service. ${ }^{63}$ Usually, the company also acts as the business's Responsible Organization (RespOrg) ${ }^{64}$ RespOrgs reserve numbers for subscribers by entering the appropriate routing data into a database called the Service Management System (SMS). The number is then assigned to the busmess for use. ${ }^{65}$

Database Management Services, Incorporated (DSMI), which is a subsidiary of Bellcore and manages the toll-free system, administers the SMS and classifies toll-free numbers into one of nine categories according to present status. ${ }^{66} \mathrm{~A}$ "spare" number is immediately available from the SMS database upon request by a RespOrg. The RespOrg then obtains control of the number, which moves to a "reserve" status. Under a recently adopted certification requirement, the RespOrg's act of reserving numbers certifies that a specific subscriber has requested the

59. See, e.g., Cardservice Int'1, Inc. v. McGee, 950 F. Supp. 737 (E.D. Va. 1997) (applying the seven-factor Pizzeria Uno test, but noting that the similarity of marketing channels is more important in Internet cases because only one party can use any one domain name), affd, 1997 U.S. App. LEXIS 32267 (4th Cir. Nov. 18, 1997).

60. See, e.g., Toys "R" Us, Inc. v. Akkaoui, 1996 WL 772709, at *3 (N.D. Cal. Oct. 29, 1996) (enjoining the use of "adultsrus.com" or any variation of the famous and distinctive mark "Toys ' $R$ ' Us" by the on-line vendors of sexual devices and clothing, explaining that "Adults R Us' tarnishes the ' $R$ Us' family of marks by associating them with a line of sexual products that are inconsistent with the innage Toys ' $R$ ' Us has striven to mamtain for itself').

61. See Fourth Report and Order, supra note 33, I 39 (vanity numbers); Network Solutions, Inc., Network Solutions' Domain Name Dispute Policy (Rev. 03) I 1 (visited Mar. 24, 1998) <http:// www.netsol.com/rs/dispute-policyb.html> [hereinafter Domain Name Dispute Policy] (domain names). Certain 888 numbers, which the FCC suppressed in 1996, are excluded from the first-come, first-served policy; the FCC allowed a right of first refusal for holders of those set-asides. See Fourth Report and Order, supra note 33, IJ 29-30.

62. First Report and Order, supra note 33,916 (quoting AT\&T).

63. See Notice of Proposed Rulemaking, supra note 1, I6.

64. See id. I 7 ("Any entity that meets certain eligibility criteria may serve as a RespOrg.").

65. See id. I 7 n.16. RespOrgs perform oversight functions for subscribers, such as modifying data in the database and troubleshooting, until the numbers are disconnected. See id. I 7 n.19.

66. See id. I 17. 
number for service. ${ }^{67}$ Once the RespOrg enters routing data for a specific subscriber, the number has an "assigned" status. A number shifts into "working" status when the subscriber begins using the number for toll-free calls. ${ }^{68}$ Unfortunately, the registration system used by DSMI and the FCC generates problems of consumer confusion and number brokering.

\section{Consumer Confusion: Equivalent and Complementary Numbers}

With the release of the new toll-free prefixes, the FCC's first-come, first-served registration policy will heighten already existing consumer confusion. The simplicity of the policy does not compensate for its inability to resolve disputes between the conflicting, equally legitimate claims of multiple parties to a single toll-free number. Even if a business holds an 800 number that incorporates its trademark, a competitor or number broker may reserve an equivalent vanity number in a different prefix merely by being the first to reserve the number.

In addition, consumer confusion already exists because of the presence of complementary numbers. A complementary number is one that consumers frequently dial when attempting to reach a similar number. ${ }^{69}$ Experts in the telecommunications and cognitive psychology fields have found that certain digits and letters are often confused. For example, Sprint Corporation discovered with its toll-free number 800-PINDROP that "[p]eople often confuse the letter ' $O$ ' and zero when they dial."70 The same problem occurs when people try to contact Dollywood, Dolly Parton's amusement theme park in Tennessee. The number for the park is 1-800-DOLLYWOOD, but callers who dial 800-D[zero]LLYWOOD reach a telephone sex line. ${ }^{71}$ Confusion also may arise between the letters $I$ or $L$ and the number one, or even between two numbers, such as

67. See Second Report and Order, supra note 15, I 25. The FCC adopted the certification requirement to prevent warehousing, or the stockpiling of unused numbers without identifying subscribers for those numbers. See id. I 19.

68. See Notice of Proposed Rulemaking, supra note 1, I 17. "Disconnect" numbers are disconnected and have intercept recordings advising callers of the disconnection. See id. "Transitional" numbers are disconnected numbers that no longer furnish an intercept recording and will revert to spare status after a certain period of time. See id. Numbers in "suspended" status are temporarily disconnected due to billing disputes, but can be reactivated after resolution of the problem. See Second Report and Order, supra note 15, 155 . DSMI classifies numbers for special or one-time events, such as the Olympics or political campaigns, as "unavailable" for assignment during the period prior to usage. Id. I 51. Numbers that are not available for general assignment are classified as "NXX not open." Notice of Proposed Rulemaking, supra note 1, 17.

69. See Holiday Inns, Inc. v. 800 Reservation, Inc., 86 F.3d 619, 620-21 (6th Cir. 1996).

70. Barry Meier, For a Special Number, Dial (800) VANITY, N.Y. TimEs, July 11, 1992, at 146.

71. See Holiday Inns, Inc. v. 800 Reservation, Inc., 838 F. Supp. 1247, 1251 (E.D. Tenn. 1993) (describing the problem with 800-DOLLYWOOD), rev'd, 86 F.3d 619 (6th Cir. 1996). I discovered this fact myself when I dialed 800-D[zero]LLYWOOD. 
3 and $8 .^{72}$ Moreover, complementary numbers may derive from caller misspellings. AT\&T found that some people fail to reach its collect-call service at 800-OPERATOR because they dial 800-OPERATER. ${ }^{73}$

The complementary number phenomenon provides competitors and number brokers with additional opportunities to profit from consumer confusion. Individuals or businesses who intend to divert business from an established company and free-ride on its reputation may attempt to do so by reserving its complementary numbers. In Holiday Inns, Inc. v. 800 Reservation, Inc. ${ }^{74}$ a travel agency owner reserved 800-H[zero]LIDAY - the complementary number for Holiday Inns' toll-free line, 800-HOLIDAY. The travel agency warned callers that they had not reached Holiday Inns, but offered to make reservations with Holiday Inns and other hotel chains. The defendant acknowledged that he based his busimess on the fact that "the more frequently Holiday Inns advertised its vanity number, the more business be would receive." $" 75$

Similarly, U-Haul International canceled a contract with a dealership that acquired complementary numbers to U-Haul's toll-free number, 800-GO-U-HAUL. ${ }^{76}$ The numbers, which included 800-GO-UHALL, 800-G[zero]-U-HAUL, and 800-G[zero]-U-HALL, capitalized on consumer confusion from mistaken characters and misspellings. ${ }^{77}$ Although no litigation has arisen between the holders of toll-free numbers and number brokers who have reserved complementary numbers and seek to sell them back to the business, such a scenario is far from impossible.

Although the FCC acknowledges that the release of new SACs is likely to cause consumer confusion, it has not adopted a dispute resolution policy to cope with such scenarios. ${ }^{78}$ The DSMI registration system currently integrates an aging process to reduce consumer confusion, but the mechanism is insufficient to resolve issues of consumer confusion over toll-free numbers because the process only addresses errors

72. See Holiday Inns, 86 F.3d at 621 .

73. See Maney, supra note 3, at B2.

74. 838 F. Supp. at 1247.

75. Id. at 1252 .

76. See U-Haul Int'l, Inc. v. Kresch, 943 F. Supp. 802, 804 (E.D. Mich. 1996).

77. See id.

78. See Second Report and Order, supra note $15, \mathrm{I} 68$ (explaining that "there is a strong likelihood that a subscriber with a seveu-digit number in one toll free code corresponding to a high volume seven-digit number in another toll free code might receive many misdialed calls," but rejecting the adoption of any measures to prevent consumer confusion); id. I 72 (noting its belief that "public education and awareness campaigns will address consumer confusion"); First Report and

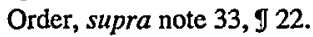


between former and current users of the same number. Mistakes due to equivalent and complementary numbers are not addressed. ${ }^{79}$

Aging is "the period of time between disconnection or cancellation of a toll-free number and the point at which that toll-free number may be reassigned to another subscriber." 80 The aging process system thus includes lag times, which are intervals of time between the different categories of use of a number by one entity and its availability for use by another entity. Currently, the period between removal of a number from the SMS database and reactivation is seven and one-half months. FCC rules allow a number to remain reserved for forty-five days and be assigned, but not working, for six months. ${ }^{81}$ The aging process thus attempts to protect the new user of a toll-free number from consumer confusion with the former holder, as well as prevent misdials and the related expense. ${ }^{82}$ For instance, a number may remain in disconnect status for four months. ${ }^{83}$ The FCC also intends to deter warehousing and hoarding, and to promote efficient operation and allocation of toll-free numbers, by limiting the length of lag times and aging and by penalizing violations. ${ }^{84}$

Because aging does not reduce consumer confusion caused by equivalent or coinplementary numbers, however, additional measures are necessary to protect businesses from competitors or number brokers who reserve equivalent or complementary numbers. A trademark owner can resort to litigation and obtain an injunction to lessen confusion, but the law does not provide complete protection. Reservation and use of toll-free numbers that incorporate trademarks or confusingly similar terms will not constitute a claim for infringement, despite the fact that it may lead to a loss of goodwill, unless the trademark owner shows that the defendant actively advertised the trademark. ${ }^{85}$ Thus, the current firstcome, first-served policy contributes both to consumer confusion, which may not be corrected by either the FCC or the courts, as well as number brokering.

79. See Oldham, supra note 19, at D4 ("For example, businesses with established 800 numbers were flooded with wrong-number calls when their vanity numbers were released in the 888 code.").

80. Notice of Proposed Rulemaking, supra note $1, \mathrm{~J} 19$.

81. See Second Report and Order, supra note $15,951$.

82. See Notice of Proposed Rulemaking, supra note 1, I 19.

83. See Second Report and Order, supra note 15, I 54 (explaining that reducing the disconnect interval from six to four months will result in more efficient use of numbers without causing warehousing).

84. See id. Ig 46,54 .

85. See Holiday Inns, Inc. v. 800 Reservation, Inc., 86 F.3d 619 (6th Cir. 1996); U-Haul Int'1, Inc. v. Kresch, 943 F. Supp. 802, 810 (E.D. Mich. 1996); infra Section II.B.2. 


\section{Number Brokering}

Another emerging problem that threatens to cause consumer confusion, and that is exacerbated by the FCC's first-come, first-served policy, is number brokering. Number brokers, like cybersquatters who peddle Internet domam names, ${ }^{86}$ are private individuals who predict that companies will want to obtain certam mnemonics, reserve the numbers themselves, and offer to resell them back to the busmesses that own the relevant trademark. ${ }^{87}$ The FCC prohibits the practice as contrary to the public interest, ${ }^{88}$ but many companies are willing to pay ransom money to protect their goodwill investments and prevent consumer confusion. For example, "A broker did just that with the number 1-800COLLECT. MCI supposedly paid six figures to buy the number for its collect-call service, though MCI won't talk about it." 89

The practice threatens to grow with the release of new toll-free SACs, just as an increase in the nuniber of available domain name registries niay foster cybersquatting. Trademark owners may not be able to reserve all their equivalent and complementary vanity toll-free numbers or domain name targets under the first-come, first-served policies of the FCC and NSI. Although the FCC alleviated the problem by temporarily setting aside and granting a right of first refusal for certain $888 \mathrm{num}$ bers, authorities do not plan any set-asides for the 877 SACs, 866 SACs, or global numbers. ${ }^{90}$ Given the importance of protecting investments in vanity numbers, trademarks, and trade names, it seems unlikely that the current FCC rules and penalties will be sufficient to contain the number brokering problem.

Tradeinark litigation involving vanity toll-free numbers has not yet arisen. In the context of Internet doinain names, though, courts have held that cybersquatters inay be liable for infringeinent, unfair conipetition, and dilution. ${ }^{91}$ Vanity nuniber brokers may face similar liability in the future. Although mere registration of vanity numbers and doniain names without the permission of the trademark owner does not constitute the commercial use necessary for a violation within the meaning of

86. See Intermatic, Inc. v. Toeppen, 947 F. Supp. 1227, 1233 (N.D. Ill. 1996) (defining cybersquatters); infra note 93.

87. See Maney, supra note 3, at B2.

88. See Second Report and Order, supra note 15, 9 38. The FCC imposes penalties for number brokering, including forfeiture of the numbers, termination of toll-free service, and liability for false statements. See id. \42.

89. Maney, supra note 3, at B2.

90. See Fourth Report and Order, supra note 33, 1 39; Oldham, supra note 19, at D4.

91. See, e.g., Panavision Int'l, L.P. v. Toeppen, 945 F. Supp. 1296, 1304 (C.D. Cal. 1997) (holding that defendant's cybersquatting activity violated federal trademark dilution law); Intermatic, Inc. v. Toeppen, 947 F. Supp. 1227, 1234-36 (N.D. Ill. 1996) (fimding a genuine issue of material fact as to trademark infringement and unfair competition, and holding that use of a registered trademark violated the federal and state anti-dilution statutes). 
the Lanham Act, ${ }^{92}$ intent to arbitrage trademarks is commercial use in the context of domain names. ${ }^{93}$ Thus, a number broker could be held liable for trademark infringement or dilution if a court both treats his or her attempt to resell a vanity number to the trademark holder as commercial use, and finds that the broker caused consumer confusion by reserving or using the vanity number.

92. See Holiday Inns, Inc. v. 800 Reservation, Inc., 86 F.3d 619 (6th Cir. 1996) (holding that mere reservation of a complementary toll-free vanity number without active use or advertisement of the trademark cannot constitute trademark infringement because passive exploitation of consumer confusion is not "use in commerce" under the Lanham Act); Juno Online Servs. v. Juno Lighting, Inc., 979 F. Supp. 684, 691-92 (N.D. Ill. 1997) (finding that the Lanham Act requires actual use of the Internet, not mere reservation of a domain name); infra Section Il.B.2.

93. See Intermatic, 947 F. Supp. at 1239; Panavision Int'l, 945 F. Supp. at 1303. For example, Dennis Toeppen is a well-known cybersquatter. He has registered approximately 240 domain names, including "aircanada.com," "eddiebauer.com," and "yankeestadium.com." See Intermatic, 947 F. Supp. at 1230; Panavision Int'l, 945 F. Supp. at 1300. In Panavision, the court held that Toeppen violated anti-dilution statutes by demanding $\$ 13,000$ from Panavision, which owns federal trademarks for Panavision and Panaflex. Toeppen had registered "panavision.com," a web site that displayed aerial views of Pana, Illinois, and "panaflex.com," which merely said, "hello." The court found that "[Toeppen'sl conduct injured Panavision by preventing Panavision from exploiting its marks and it injured consumers because it would have been difficult to locate Panavision's web site if Panavision had established a web site under a name other than its own." Panavision Int'l, 945 F. Supp. at 1303. In Intermatic, the court held,

Dilution of Intermatic's [incontestable] mark is likely to occur because the domain name appears on the web page and is included on every page that is printed from the web page .... . TThe most corrosive and irreparable harm attributable to tradeınark infringement is the inability of the victim to control the nature and quality of the defendant's goods.

947 F. Supp. at 1240.

Doinain names have also been used as a means to advocate political and social mcssages. See, e.g., Planned Parenthood Fed'n of Am., Inc. v. Bucci, No. 97 Civ. 0629, 1997 WL 133313 (S.D.N.Y. Mar. 24, 1997) (holding that promotion of an anti-abortion book by a Catholic Radio host who exploited the domain name "plannedparenthood.com;" thereby misleading pro-abortion Internet users as to the site's origin, infringed plaintiff's trademark and was not subject to First Amendment protection because it served a source identification function rather than communicating a message); Wendy R. Leibowitz, Green Paper on 'Net Names Still Leaves Many Questions Unsettled, Nat'L L.J., Feb. 16, 1998, at B7 (explaining that a supporter of Senator Alfonse D'Amato registcred "ferraro.org" to prevent D'Amato's rival, Geraldine Ferraro, from cstablishing a web sitc at that address).

Yet another group of Internet poachers has engaged in jokcs, or "cyber jinks," by reserving established trademarks as domain names. For example, the test preparation company Princcton Review registered "kaplan.com" as a joke to mock its rival, Stanley Kaplan Education Centers, posted ads for Princeton Review courses, made disparaging comments about the quality of Kaplan classes, and eventually proposed to surrender the doinain name in exchange for a case of bcer, domestic or imported. See Hamilton, supra note 57, at 7; Sterling, supra note 50, at 738. Kaplan rejected the offer and filed suit, prompting Princeton Review's president to rcmark that his rival had "no sense of humor, no vision, and no beer." See Sterling, supra note 50, at 739. Princeton Review also threatened to continue disparaging Kaplan by registering "kraplan.com." See Hamilton, supra note 57, at 7. However, the case went to binding arbitration, where the panel found for Kaplan and ordered Princeton Review to transfer "kaplan.com" to its rival. See id. at 7; Hamilton, supra note 57, at 6-7. 


\section{FCC and Industry Proposals to Reduce Consumer Confusion and Resolve Disputes over Toll-Free Numbers}

With the myriad problems discussed above in mind, the FCC and members of the toll-free telephone industry have each made different policy proposals that address issues of consumer confusion and attempt to forestall or reduce trademark conflicts. ${ }^{94}$ The FCC has traditionally entrusted the industry with the settlement of disputes regarding toll-free numbers and has only stepped in when absolutely necessary. ${ }^{95}$ The FCC has rejected the establishment of any formal, mandatory dispute resolution process because it asserts that the current first-come, first-served policy precludes conflicts over the superiority of rights to toll-free numbers. ${ }^{96}$ Moreover, the FCC believes that sufficient public education and awareness campaigns regarding the release of new SACs will minimize consumer confusion and misdialing. ${ }^{97}$ Opponents of dispute resolution argue against the admimistrative burden, expense, and delay associated with the adoption of such a system, as well as the difficulty of finding an acceptable standard to determine who may use the number when parties have equally valid claims. ${ }^{98}$

Given the amount of confusion that resulted from release of the 888 prefix and the potential for further confusion, litigation, and illegal activity from the addition of the 877 prefix, it seems clear that the FCC should play a more active role and institute some form of dispute resolution. In an attempt to resolve the issues above, government agencies, the telecommunications industry, and businesses utilizing toll-free vanity numbers have made suggestions along those lines. These proposals, however, are not without their own shortcomings.

94. The Clinton administration proposed an auction for the 374,199 toll-free 888 numbers set aside by the FCC. The White House, which suggested the idea in its 1996 and 1997 budgets, invoked the FCC's policy of treating toll-free numbers as valuable public resources. See Thom Weidlich, \$700M Going Once: Proposed Budget Would Auction Off Toll-Free Numbers, 9 Cowles Bus. MEDIA 15 (1997). The administration estimated that the schenie could collect $\$ 700$ million over three years. See id. Congress backed industry opposition to the proposal. See U.S. Would Auction Toll-Free 888 Numbers Under Clinton Budget, WALL ST. J., Mar. 20, 1996, at A8. The FCC rejectcd the idea of an auction or lottery for the set-asides and all newly released toll-free numbers because the agency feared that businesses and individuals would resort to number brokering and manipulation of the system. See Fourth Report and Order, supra note 33, I 16. The FCC also noted that administration of an auction or lottery would delay the release of numbers. Moreover, an auction would disadvantage snrall businesses, which could not compete with the resources of larger companies. Finally, the appropriate recipient of auction proceeds was unclear because 18 countries use the U.S. toll-free nunbering system. See id.

95. See Notice of Proposed Rulemaking, supra note 1, I 10 (recognizing that the industry needed assistance to best effectuate the transition to the 888 prefix; and therefore, seeking to provide a framework for the shift).

96. See First Report and Order, supra note 33, I 23.

97. See Second Report and Order, supra note 15, I 72.

98. See First Report and Order, supra note 33, I 20. 


\section{Right of First Refusal}

Many businesses that hold 800 vanity numbers have demanded a right of first refusal for equivalent numbers with different prefixes. ${ }^{99} \mathrm{~A}$ right of first refusal would give holders of 800 numbers the option to receive equivalent numbers with different prefixes, thereby allowing businesses to prevent consumer confusion and number brokering and continue customer association of the mnemonic with the company. ${ }^{100}$

The FCC demied a right of first refusal for holders of toll-free numbers with the 877 prefix and all future SACs. ${ }^{101}$ As a practical matter, the FCC must deny the right because granting it would automatically deplete a large portion of any new pool of numbers. That effect would defeat the purpose of releasing new prefixes and would result in an inefficient use of numbers. ${ }^{102}$ Also, the FCC is concerned about the escalation of administrative costs from polling subscribers to determine their rights prior to the opening of each new prefix. ${ }^{103}$ Furthermore, a right of first refusal is inconsistent with the FCC's policy that phone numbers are a public resource, and as such are not subject to ownership interests. ${ }^{104}$ Finally, adoption of a right of first refusal could cause inequity under the FCC's first-come, first-served rule. A company with an inferior right to a mnemonic may be the first to reserve the number and thereby receive the right of first refusal. ${ }^{105}$ Therefore, even if the industry established a right of first refusal, a dispute settlement procedure would still be necessary.

The FCC distinguishes between toll-free numbers with an 800 and 888 prefix, and those with an 877,866 , or other future prefix. ${ }^{106}$ As a result, the FCC granted a right of first refusal only for the 888 set-aside numbers because it recognized that the dialing public is still adjusting to the concept of multiple toll-free prefixes. ${ }^{107}$ The FCC acknowledges that the release of the 888 and 877 , and future SACs will cause consumer confusion, misdialing, and free riding on competitors' goodwill, but the

99. See Oldham, supra note 19 , at D4.

100. See Notice of Proposed Rulemaking, supra note 1 , I 41.

101. See Fourth Report and Order, supra note 33, I 30; Oldham, supra note 19, at D4.

102. See Fourth Report and Order, supra note 33, Ig 17-18; Notice of Proposed Rulemaking, supra note $1, \mathrm{~J} 42$.

103. See Fourth Report and Order, supra note 33, I 19.

104. See id. I 20.

105. A senior user is the first user to adopt and use a mark in order to sell a product; a junior user is the second or subsequent seller and user of the mark. See 4 MCCARTHY, supra note 47, $\$ 26: 1$; infra Section II.A.2 (describing priority of rights between a federal registrant and non-registrant and between two non-registrants).

106. See Fourth Report and Order, supra note 33, I9 29-30.

107. See id. I 29 ("As subsequent toll free codes are introduccd, customers will become more cognizant that there are numerous toll free codes thus, rcducing instances of confusion and misdialing."). 
agency limited a right of first refusal to 888 numbers because they belong to the first new SAC in almost thirty years. ${ }^{108}$

\section{Industry Classifications}

The federal Bureau of the Census numerically categorizes every service and industry with standard industrial classification (SIC) codes. ${ }^{109}$ In 1995, the FCC considered an industry classification system that would allow businesses in non-competing industries to own the same number and mnemonic but with different prefixes. ${ }^{110}$ According to the proposal, every service and mdustry of the economy would receive a numerical code. A business with an 800,888 , or 877 number wouId report its code to its commercial carrier, which would relay the information to DSMI. DSMI would enter the data in the SMS database. Likewise, a company applying for a new number would advise its RespOrg of its industry code. The RespOrg wouId convey the inforination to DSMI, which would check the SMS database to determine whether the holders of existing numbers and the applicant reported the saine code. If so, the subscriber, as a competitor of the current holder, could not reserve the new number. The industry codes would apply to all of the toll-free prefixes as new subscribers entered the system. ${ }^{111}$

An industry classification system would recognize the inherently exclusive nature of toll-free numbers. Unlike traditional trademark law, which permits businesses in non-competing industries to own nonexclusive trademark rights in a word or name, current telecommunications technology mandates that only one business can hold each unique phone number. By allowing non-competitors to use the same mnemonic in different prefixes, the industry classification system would function in a manner analogous to standard trademark law. Nevertheless, because registration of numbers under a classification system would not distinguish between senior and junior users within any one industry, the system would work best in conjunction with a dispute resolution process. A senior user could then challenge a junior user's use of a mnemonic.

Also, establishment of an industry classification system would trigger a flood of disputes between current holders of mnemonics that have different SACs but are otherwise identical and are associated with the same industry. Furthermore, a classification system would involve too heavy an administrative burden, both to mitiate the industry codes and

108. See id. I 29.

109. See id. I 45 ("Codes with a greater number of digits provide more detailed product classifications. For example, the SIC code ' 20 ' signifies 'food and kindred products,' while the SIC code '2095' signifies 'roasted coffee."').

110. See Notice of Proposed Rulemaking, supra note 1, I 44.

111. See id. 
to update them to reflect the diversification and merger of companies. ${ }^{112}$ According to the FCC, the agency would also incur enforcement costs to prevent businesses from using misrepresentations to manipulate their classification. ${ }^{113}$

\section{Gateway Intercepts}

A gateway intercept is a recorded message, like an automated voice mail system, that enables a dialer to choose the recipient of his or her call. "14 "That is, when a consumer called either '1-800-THE-CARD' or '1-888-THE-CARD,' he would first reach an intercept message that would help him clarify which entity he wanted to reach before the call was completed."115 Proponents have urged carriers to use gateway intercepts for all toll-free calls. Such a system is the clearest way to prevent consumer confusion because it gives callers the option to choose from a selection of businesses with confusingly similar vanity numbers.

The FCC, however, declined to impose a gateway intercept requirement. ${ }^{116}$ It found that gateway intercepts could annoy callers, inflict expense on the toll-free holder, and "increase post-dial delay, call setup times, aud access times." 117 Furthermore, the technology required to back a system-wide adoption of gateway intercepts is not currently available. ${ }^{118}$ Instead, businesses may voluntarily use their own intercept messages.

\section{Partitioning}

The FCC defines partitioning as the assignment of specific toll-free prefixes to certain types of toll-free service. ${ }^{119}$ If the industry partitioned toll-free service, for example, businesses and most vanity number holders could use 800 numbers, personal and paging subscribers could retain use of 888 numbers, and 877 numbers could be allocated to data and fax subscribers. ${ }^{120}$ Partitioning would end consumer confusion from equivalent toll-free numbers, if not complementary numbers, because businesses could not repeat vanity numbers in different prefixes. Partitioning would also eliminate the number brokering market for equivalent numbers. ${ }^{121}$

\footnotetext{
112. See Fourth Report and Order, supra note 33, I 15.

113. See id.

114. See Notice of Proposed Rulemaking, supra note 1, I 46.

115. Id.

116. See Second Report and Order, supra note $15,975$.

117. Id.

118. See id.

119. See id. I 64 .

120. See id.

121. See id. 167.
} 
The FCC, though, found that partitioning would result in discrimination because " 800 numbers would, at least imitially, enjoy greater recognition than would numbers in new toll-free SACs." 22 The primary problem with partitioming is its potential cumulative administrative burden. First, partitioming would force a large number of subscribers to shift prefixes. The change could disturb paging services, cause companies to suffer misdials and possibly a loss of business, and make it more difficult for consumers to reach desired services initially. Moreover, even if the industry could support the immediate opening of multiple new SACs, it would prove inefficient and expensive to do so when the inarket for alternate prefixes is uncertain and the 800 prefix is inadequate to meet the demand for business and personal vanity numbers. ${ }^{123}$

II

Analysis of Trademark Issues Concerning TOLL-Free VANtTy Telephone Numbers

When consumer confusion arises over equivalent or compleinentary vanity numbers, the courts attempt to apply a traditional trademark analysis. Thus, the law generally treats telephone mnemonics as norinal word marks. It disregards the underlying numbers, ${ }^{124}$ and instead protects vanity numbers from trademark infringement and unfair competition by invoking both state common law $^{125}$ and the federal Lanham Trademark Act (Lanham Act). ${ }^{126}$ The inherent limitations of the telecommunications medium, however, demands that the law shape its rules to the technology. ${ }^{127}$ This Part will review the traditional law of trademarks and discuss emerging trends in case law, which suggest that courts are beginning to recognize the special issues raised by telecommunications technology and the vanity toll-free telephone industry.

\section{A. State Common Law and Federal Trademark Protection}

Trademarks and service marks identify goods and services, and the sources of those goods and services for consumers. ${ }^{128}$ A primary

122. Second Report and Order, supra note $15, \mathbb{I} 67$.

123. See id. I 67.

124. See, e.g., Kelley Blue Book v. Car-Smarts, Inc., 802 F. Supp. 278 (C.D. Cal. 1992).

125. See Dial-A-Mattress Franchise Corp. v. Page, 880 F.2d 675, 678 (2d Cir. 1989); Murrin v. Midco Communications, Inc., 726 F. Supp. 1195, 1201 (D. Minn. 1989).

126. 15 U.S.C. $\$ \S 1051-1127$ (1996).

127. See Horky, supra note 22 , at 230 ("The courts have forced mnemonics into the traditional categories even though their technological anomalies require special consideration.").

128. A trademark is "any word, name, symbol, or device, or any combination thereof," which a person uses in commerce "to identify and distinguish his or her goods ... from those manufactured or sold by others and to indicate the source of the goods, even if that source is unknown." 15 U.S.C. $\S$ 1127 (1994). A service mark identifies and distinguishes services mstead of products. See id. I will 
purpose of trademark law is to prevent consumer confusion as to the origin of goods and to allow consumers to identify and acquire the goods that they desire. Trademark law also protects the creation and perpetuation of businesses' goodwill. Goodwill is the intangible, but valuable, image and reputation in which businesses invest large amounts of effort and money. ${ }^{129}$

\section{Classification of Trademarks}

The courts classify marks according to their strength or level of distinctiveness because only distinctive marks receive protection. ${ }^{130}$ lnherently distinctive marks, which include arbitrary or fanciful marks and suggestive marks, automatically receive protection. ${ }^{131}$ An arbitrary mark, such as "Black \& White" for scotch whiskey, does not logically suggest or describe the goods or its characteristics, and a fanciful mark, like "Exxon" for gas, is coined and has no meaning at all.132 Consumers who see arbitrary or fanciful marks understand that the marks serve no other function than indication of origin because there is no rational connection between the mark and the good or service. ${ }^{133}$ Suggestive marks such as "Coppertone" require the consumer to exercise imagination or thought to infer the nature of the goods or service because the mark only indirectly describes the product or its features. ${ }^{134}$ Descriptive marks, like "Bed \& Bath", ${ }^{135}$ describe a good or service, its characteristics or quality, or its geographical source. Descriptive marks are not inherently distinctive or protected because consumers generally view the mark as a description of the good or service, not as an indicator of origin. However, a descriptive mark can become distinctive by acquiring secondary meaning. ${ }^{136}$ Secondary meaning develops when the public comes to associate a mark with the origin of the good or service, rather

use the terms trademark and service mark interchangeably because the registration and protection of both are identical under the Lanham Act. 15 U.S.C. \$ 1053 (1994).

129. See 1 MCCARTHY, supra note 47, §§ 2:15-20.

130. See Abercrombie \& Fitch Co. v. Hunting World, Inc., 537 F.2d 4, 9-11 (2d Cir. 1976) (Friendly, J.) (outlining the classification of trademarks).

131. See 2 MCCARTHY, supra note 47 , § $11: 2$ (differentiating inherently distinctive from noninherently distinctive categories).

132. See id. $\S \S 11: 4,11: 5,11: 11$; see also Fleischmann Distilling Corp. v. Maier Brewing Co., 314 F.2d 149, 154 (9th Cir. 1963) ("Black \& White"); Exxon Corp. v. Xoil Energy Resources, 1nc., 552 F. Supp. 1008, 1014 (S.D.N.Y. 1981) ("Exxon").

133. See Zatarains, Inc. v. Oak Grove Smokehouse, Ine., 698 F.2d 786, 791 (5th Cir. 1983).

134. See id.

135. See Leejay, Inc. v. Bed Bath \& Beyond, Inc., 942 F. Supp. 699, 702 (D. Mass. 1996) (holding that "Bed Bath \& Beyond" did not infringe upon "Bed \& Bath" because "Bed \& Bath" was generic or descriptive).

136. See Zatarains, 698 F.2d at 790; 2 McCARTHY, supra note 47 , $\S 11: 15,11: 25$. 
than merely regarding the mark as a descriptive word. ${ }^{137}$ "[P]roof of substantially exclusive and continuous use" in commerce for five years is prima facie evidence of secondary meaning. ${ }^{138}$ The courts protect descriptive marks that have secondary meanings because use of the marks by others may cause consumer confusion.

A generic inark indicates a genus or general class of products or services, but does not describe the particular, individual qualities of the product or service. ${ }^{139}$ For example, "jeans" is a generic term. Generic marks are not protected because they cannot identify or distinguish the source of the goods or services. ${ }^{140}$ Some trademarks, like "aspirin," become generic through a process of genericide when the public appropriates the term as a common name for an entire category of products. ${ }^{141}$

\section{Geographic Limits on Trademark Use}

The owner of a trademark registered on the PTO's Principal Register has superior, nationwide protection, regardless of the scope of the territory of actual use. ${ }^{142}$ "However, the federal registrant cannot enjoin a local junior user until a likelihood of the registrant's expansion into that area is proven." 143 Similarly, a nonregistering party can retain exclusive rights in certain geographic areas by showing use of the mark in that area prior to the registrant's filing of his application. ${ }^{144}$

The Lanham Act provides broader territorial rights to federal registrants than state common law. ${ }^{145}$ Absent the ownership of federal registrations, trademark rights under state common law will largely turn on the priority and scope of use. ${ }^{146}$ The common law automatically provides ownership without registration when a person uses an inherently distinctive inark in trade or commerce, or a descriptive mark acquires secondary meaning. ${ }^{147}$ An mdividual obtams priority of rights in a mark by becoming a senior user, or the first to use the mark in commerce. However, the common law limits the mark holder's exclusive use to the

137. See Zatarains Inc., 698 F.2d at 791; Little Tavern Shops, Inc. v. Davis, 116 F.2d 903, 906 (4th Cir. 1942) (finding that although "Little Tavern" was descriptive of plaintiff's eating shops, the mark had acquired secondary meaning).

138. 15 U.S.C. $\$ 1052(f)$ (1994).

139. See Abercrombie \& Fitch Co. v. Hunting World, Inc., 537 F.2d 4, 9 (2d Cir. 1976).

140. See Bellsouth Corp. v. Datanational Corp., 60 F.3d 1565, 1569 (Fed. Cir. 1995).

141. See Murphy Door Bed Co. v. Interior Sleep Sys., Inc., 874 F.2d 95, 100-01 (2d Cir. 1989)

(Murphy bed); Bayer Co. v. Umited Drug Co., 272 F. 505 (S.D.N.Y. 1921) (aspirin).

142. See 15 U.S.C. \$ 1057(c) (1994).

143. 4 McCARTHY, supra note $47, \S 26: 31$.

144. See id. \$ 26:4.

145. See id. $\$ 26: 32$.

146. Holders of unregistered trademarks can initiate infringement actions under the Lanham Act. See 15 U.S.C. § 1125(a) (1994).

147. See 15 U.S.C. $\$ 1125(a)$. 
geographic area in which the business operates or has established goodwill. ${ }^{148} \mathrm{~A}$ junior user, or subsequent seller and user of the trademark, receives exclusive rights to use the same mark in a remote geographic area if the junior user acts in good faith. ${ }^{149}$ In this context, good faith is shown by a lack of knowledge or notice of the senior user's use in the other area. ${ }^{150}$ "Similarly, the junior user cannot enter market areas where the senior user has established exclusive rights. Each user of the contested mark may have its own exclusive areas of trademark use. Neither can enter the market area of the other."151 In other words, the common law allows more than one individual to carve out areas of exclusive, concurrent use of the same mark. ${ }^{152}$

\section{Trademark Infringement}

The Lanham Act permits trademark infringement actions against those who make unauthorized use of marks that are identical or similar to valid marks when such use is likely to cause confusion as to the origin or sponsorship of the goods or services. ${ }^{153}$ Courts apply different multi-factor likelihood of confusion tests to determine whether use of the allegedly infringing mark is likely to cause confusion as to the source, affiliation, or sponsorship of goods or services. ${ }^{154}$ Trademark

148. See E. F. Prichard Co. v. Consumers Brewing Co., 136 F.2d 512, 522 (6th Cir. 1943).

149. See Money Store v. Harriscorp Finance, Inc., 689 F.2d 666, 674-75 (7th Cir. 1992); Johanna

Farms, Inc. v. Citrus Bowl, Inc., 468 F. Supp. 866 (E.D.N.Y. 1978).

150. See Money Store, 689 F.2d at 666; Johanna Farms, 468 F. Supp. at 866.

151. 4 MCCARTHY, supra note $47, \S 26: 3$.

152. See id. \$\$ 26:2-4.

153. See 15 U.S.C. $\$ 1114(1)$ (1994) (registered marks); 15 U.S.C. $§ 1125$ (a) (1994) (unregistered marks). Companies in non-competing industries may use the same mark. For example, Prince spaghetti and Prince tennis rackets are not sufficiently close product lines to generate consumer confusion. See Jonathan E. Moskin, Postcards from the Internet: Dontain Name Infringement, N.Y. L.J., Mar. 10, 1997, at S6.

154. In AMF Inc. v. Sleekcraft Boats, for example, the Ninth Circuit applicd a sct of fairly common factors, including: (1) strength of the mark, or level of distinctiveness and marketplace recognition; (2) proximity or relatedness of the types of goods or services; (3) similarity of the marks in sight, sound, and meaning; (4) evidence of actual consumcr confusion, i.e., testimony of confused consumers, misdirected communications, or consumcr surveys; (5) markcting channels used to distribute the goods or services and the type of media used to advertise; (6) type of goods, their expense, and the degree of care and sophistication likely to be exercised by the purchaser; (7) defendant's intent in selecting a mark, i.e., bad faith adoption of a confusingly similar mark or misappropriation of another's goodwill; and (8) likelihood of expansion or diversification of the product lines. See AMF Inc. v. Sleekcraft Boats, 599 F.2d 341, 348-49 (9th Cir. 1979). For other tests, see Keds Corp. v. Renee Int'l Trading Corp., 888 F.2d 215 (1st Cir. 1989) (8 factors); Wesco Mfg., Inc. v. Tropical Attractions of Palm Beach, Inc., 833 F.2d 1484 (11th Cir. 1987) (7 factors); Sno-Wizard Mfg., Inc. v. Eisemann Prods. Co., 791 F.2d 423 (5th Cir. 1986) (7 factors); Pizzeria Uno Corp. v. Temple, 747 F.2d 1522 (4th Cir. 1984) (7 factors); Beer Nuts, 1nc. v. Clover Club Foods Co., 711 F.2d 934 (10th Cir. 1983) (4 factors), rev'd 805 F.2d 920 (1986); Frisch's Restaurants, Inc. v. Elby's Big Boy of Steubenville, Inc., 670 F.2d 642 (6th Cir. 1982) (8 factors); Squirtco v. Seven-Up Co., 628 F.2d 1086 (8th Cir. 1980) (6 factors); Scott Paper Co. v. Scott's Liquid Gold, 589 F.2d 1225 (3d Cir. 1978) (10 factors); Helene Curtis Indus., Inc. v. Church \& Dwight Co., 560 F.2d 1325 (7th 
infringement suits protect not only the interests of consumers in identifying the source of goods and services, but also the business community's interest in maintaining investments in goodwill without undue encroachment on competition.

\section{B. Case Law Trends in Disputes Involving Toll-Free Vanity Telephone Numbers}

Although most courts treat telephone mnemonics as normal word marks and attempt to apply a traditional likelihood of confusion inquiry, courts have recognized and incorporated the analysis of issues unique to the vanity numbers industry. For example, case law distinguishes between passive and active use of vanity and complementary numbers. ${ }^{155}$ Also, the Second Circuit rejects the traditional rule for genericness in the context of toll-free vanity numbers and allows protection for generic mnemonics. ${ }^{156}$ Fimally, courts use telecommunications technology to carve out common law areas of exclusive use. ${ }^{157}$

\section{Application of Traditional Trademark Analysis to Mnemonics}

Generally, courts have analyzed telephone mnemonics as traditional word marks by examining whether there is a likelihood of confusion between two mnemonics or between a mnemonic and a trademark. ${ }^{158}$ In Kelley Blue Book v. Car-Smarts, Inc. ${ }^{159}$ the defendant offered automobile pricing information under the service marks and telephone nunibers 800-BLU-BOOK and 900-BLU-BOOK. Kelley Blue Book, which has provided autoniotive valuation goods and services since 1926 under the registered trademark "Kelley Blue Book \& Design," brought an action for trademark infringement. After applying $A M F$ 's eight-factor likelihood of confusion test, the court permanently enjoined the defendants in five western states froin use of the phrase "blue

Cir. 1977) (7 factors); Polaroid Corp. v. Polarad Elecs. Corp., 287 F.2d 492 (2d Cir. 1961) (8 factors based on the Restatement of Torts $\$ 729$ (1939)).

155. See Holiday Inns, Inc. v. 800 Reservation, Inc., 86 F.3d 619, 625 (6th Cir. 1996) (finding that passive exploitation of consumer confusion from complementary numbers does not constitute trademark infringement).

156. See, e.g., Dial-A-Mattress Franchise Corp. v. Page, 880 F.2d 675 (2d Cir. 1989) (holding that telephone mnemonics may obtain protection even if they incorporate generic terms). But see Dranoff-Perlstein Assocs. v. Sklar, 967 F.2d 852 (3d Cir. 1992) (refusing to extend protection to mnemonic phone numbers that correlate with generic terms).

157. See, e.g., Dial-A-Mattress, 880 F.2d at $677-78$ (affirming an order to notify the telephone company not to connect any calls to defendant from certain New York area codes); Murrin v. Midco Communications, Inc., 726 F. Supp. 1195, 1201 (D. Minn. 1989) (ordering defendants to notify the carrier not to connect any calls from area codes in New York and Florida).

158. See, e.g., Dranoff-Perlstein, 967 F.2d at 855 ('The mere fact that the parties' marks correspond to their telephone numbers does not substantially alter our analysis .... [M]arks which correspond to telephone numbers may be protectible.").

159. 802 F. Supp. 278 (C.D. Cal. 1992). 
book," or any confusingly similar phrase, for the advertisement, distribution, or sale of any automotive pricing information or as part of any toll-free phone number. ${ }^{160}$ Kelley Blue Book exemplifies a traditional trademark analysis in that it enjoined the use of the mnemonic because it incorporated the plaintiff's trademark, which had acquired secondary meaning as to automotive valuing guides. ${ }^{161}$

In contrast, the mnemonics at issue in Bell $v$. Kidan, ${ }^{162}$ plaintiff's CALL-LAW and defendant's 800-LAW-CALL, did not embody the parties' trade names or trademarks. The plaintiff, a personal injury attorney, used and advertised CALL-LAW in three local New York area codes for five years. Nevertheless, the court described it as a weak mark that was "hardly distinguishable from other similar mnemonic devices, such as L-A-W-Y-E-R-S." ${ }^{163}$ In addition, the court said, even unsophisticated consumers could perceive a difference between toll-free and regular calls. That fact, said the court, affected the similarity of the marks: "[A]n ordinary customer would expect even slight variations in a telephone mnemonic to yield an entirely different number."164 Thus, although it dismissed obvious similarities between the mnemonics CALL-LAW and LAW-CALL, the Bell court, unlike the Kelley Blue Book court, incorporated a recognition of the toll-free nature of 800 LAW-CALL into its application of the traditional likelihood of confusion factors.

\section{Passive Use Versus Active Use of Trademarks}

Because the Lanham Act just prohibits the use of confusingly similar marks if the defendant used the allegedly infringing mark "in commerce," courts only enjoin active attempts to trade on the established goodwill of another's trademark. ${ }^{165}$ Passive receipt of benefits

160. See id. at $286-94$.

161. See id. at $285-86$ (concluding that the term "blue book" alone can refer to blank exam books, social directories, telephone directories, and other products, but is not generic for automotive valuation guides); see also Multi-Local Media Corp. v. 800 Yellow Book, Inc., 813 F. Supp. 199 (E.D.N.Y. 1993) (applying a seven-factor test to find that the number 800-Y-E-L-L-O-W-B-O-O-K is confusingly similar to a classified phone directory's trademark "Yellow Book," which has acquircd secondary meaning, despite inclusion of "800," which is a generic term for toll-free calling); American Airlines, Inc. v. A 1-800-A-M-E-R-I-C-A-N Corp., 622 F. Supp. 673 (N.D. Ill. 1985) (enjoining the use and advertisement of $800-A-M-E-R-I-C-A-N$ or any confusingly similar name for air transportation or rcservation serviccs).

162. 836 F. Supp. I25 (S.D.N.Y. 1993).

163. Id. at 127.

164. Id.

165. 15 U.S.C. $\$ 1114$ (1)(a) (1994) (forbidding the "use in commerce [of] any reproduction, counterfeit, copy, or colorable imitation of a registercd mark... which ... is likely to cause confusion"); 15 U.S.C. $\$ 1125$ (a) (1994) (allowing actions against one who "uscs in commerce any word, term, name, symbol, or device... or any false designation of origin, false or misleading description of fact, or false or misleading representation of fact ... "). 
based on that same goodwill is an insufficient basis for an injunction. In other words, a company may reserve and use an equivalent or complementary number even if it causes consumer confusion and allows free riding on a competitor's established goodwill; however, businesses may not actively advertise a plaintiff's mark as part of its company name or vanity number. For example, in American Airlines, Inc. v. A 1-800$A-M-E-R-I-C-A-N$ Corp., the defendant actively used and advertised the plaintiff's mark as part of its company name and toll-free vanity number. The court issued an injunction against a travel agency that arranged its directory listings as A 1-800-A-M-E-R-I-C-A-N Corp. under the "Airline Companies" heading of approximately fifteen million yellow pages directories in the United States and Canada. ${ }^{166}$ The court held that Ainerican Airlines showed secondary meaning in the name "American" and a likelihood of success on the merits in its trademark infringement claim. The court relied on the defendant's own records, which showed actual confusion by callers, and the defendant's intent, expressed in two media interviews, to palm off his company as American Airlines. ${ }^{167}$ By using the plaintiff's trademark, the defendant in American Airlines caused consumer confusion as to the source of his services and traded off the plaintiff's goodwill.

Likewise, in Holiday Inns, Inc. v. 800 Reservation, Inc. ${ }^{168}$ the Sixth Circuit held that the passive exploitation of consumer confusion from complementary numbers is not "use in commerce" and, therefore, cannot constitute trademark infringement. ${ }^{169}$ In Holiday Inns, a travel agency admitted its intent to derive passive benefit from Holiday Inns' reputation and advertisements. However, the travel agency did not actively advertise or use the Holiday Inns trademark. The agency merely took advantage of errors made by callers, who tried to reach Holiday Inns' toll-free line 800-HOLIDAY, but mistakenly dialed the complementary number 800-H[zero]LIDAY. The Sixth Circuit emphasized that "the defendants did not create any confusion; the confusion

166. See 622 F. Supp. 673 (N.D. IIl. 1985).

167. See id. at 679 ("Members of the public seeing 1-800's advertisement in the yellow pages under "Airline Companies," the court explained, "would assume they were communicating with American. That in fact happened. [The defendant] expected it and counted on it.").

168. 86 F.3d 619 (6th Cir. 1996).

169. See id. at 625-26; U-Haul Int'l, Inc. v. Kresch, 943 F. Supp. 802, 810 (E.D. Mich. 1996) (holding that a former U-Haul dealership did not infringe U-Haul's toll-free number 800-GO-U-HAUL by connecting complementary numbers because defendant did not promote the complementary numbers as mnemorics and "owning a complementary number, alone, is not a violation of the Lanham Act. Instead, a showing of actual use of the mark, i.e., the vanity number, must be made."); Chicago Blackhawk Hockey Team v. Madsen, 1991 WL 18411 (N.D. Ill. Feb. 13, 1991) (refusing to enjoin the passive, continued use of 312-736-H-A-W-K by the former manager of the sports hotline after termination of his contract because defendant had not advertised the number as a mnemonic). 
already existed among the misdialing public."170 Moreover, the court said, Holiday Inns never registered its vanity number as a trademark and, unlike many of its competitors, failed to forestall consumer confusion by reserving its complementary number. ${ }^{171}$

In Miss Dig Systems, Inc. v. Power Plus Engineering, Inc. ${ }^{172}$ the district court adhered to the Holiday Inns holding. Defendant Power Plus acquired 800-MISS-DIG, an equivalent number to Miss Dig's local number, 810-MISS-DIG. Unlike Holiday Inns, however, where complementary numbers allowed the defendants to profit from misdials of the mnemonic, Power Plus profited from the confusion of callers who dialed correctly but erroneously believed that Miss Dig was the source of the 800 phone line. Nevertheless, the Holiday Inns rule applied. A defendant who reserves and uses an identical core number or complementary number does not infringe the plaintiff's trademark, the court explained, unless the defendant actively promotes the corresponding vanity number in a manner that displays the plaintiff's trademark. ${ }^{173}$ Unlike the court in Bell $v$. Kidan, ${ }^{174}$ the Miss Dig court did not assume that the average caller distinguishes between toll-free and non-toll calls. The different prefixes did not affect the court's analysis because it could not reach a likelihood of confusion inquiry without a threshold finding of use in commerce.

\section{The Genericness Debate}

A third trend emerging in toll-free vanity phone number casesdealing with trademark's genericness issue-has produced controversy among appellate courts. The circuit courts of appeals are currently split over whether to protect mnemonics that consist of generic terms. The Second and Third Circuits lead the debate with the Second Circuit supporting protection for telephone mnemonics even if they are generic, and the Third Circuit denying such protection.

In Dial-A-Mattress Franchise Corp. v. Page, ${ }^{175}$ the Second Circuit upheld an injunction against the owner of a business that obtained and advertised the number 800-MATTRES(S) to sell easy beds and mattresses. The plaintiff has used the number $629-8737$, or MATTRES, in various New York area codes since 1976 and has advertised its business

170. Holiday Inns, 86 F.3d at 625.

171. See id.

172. 944 F. Supp. 600 (E.D. Mich. 1996).

173. See id. at 604 .

174. 836 F. Supp. 125 (S.D.N.Y. 1993).

175. 880 F.2d 675 (2d Cir. 1989); see also Express Mortgage Brokers, Inc. v. Simpson Mortgage, Inc., 1994 WL 465842 (E.D. Mich. May 6, 1994) (enjoining use of 800-760-CASH by a former employee because the CASH mnemonic was confusingly similar to plaintiff's phone numher 369-CASH, in which plaintiff had invested four million dollars for advertising over a ten year period). 
and phone number with the slogan "DIAL-A-MATTRESS and drop the last ' $S$ ' for savings." 176 The Second Circuit found that the plaintiff did not lose protection merely because the letters spelled a generic word. ${ }^{177}$ Although Dial-A-Mattress did not have trademark rights to the generic term "mattress," the court said, the traditional rules for genericness were insufficient in this case. "Dial-A-Mattress is not seeking protection against a competitor's use of the word 'mattress' solely to identify the competitor's name or product. What the plamtiff seeks is protection against a competitor's use of a confusingly similar telephone number and a confusingly similar means of identifying that number." 178 The court distinguished between traditional trademark law and the telephone mnemonic context. Because competitors can use generic mnemonics in other areas of advertising, the threat of anti-competitive appropriation of the terms is minimal, and the Second Circuit protected the senior user's mnemonic from consumer confusion. Junior users were merely restricted from using confusingly similar telephone innemonics. Thus, they are not wholly prevented from using generic terms in marketing. ${ }^{179}$

In contrast, the Third Circuit in Dranoff-Perlstein Associates v. Sklar ${ }^{180}$ refused to grant protection to mnemonic phone numbers that correlate with generic terms. In reaching its holding, the court emphasized the anti-competitive effects of providing one company with exclusive use of a generic mnemonic merely because it reserved the number first. "Because telephone numbers contain only an area code and seven digits, the range of commonly used alternatives which effectively communicate the same functional information as the [generic] word is severely limited in that context." law firm used and advertised INJURY-1 as its phone number for six years before Sklar, also a personal injury attorney, reserved and

176. Dial-A-Mattress, 880 F.2d at 676.

177. See id. at 678 .

178. Id.

179. See Express Mortgage Brokers, 1994 WL 465842, at *5-6 n.2 ("Trademark protection for such [generic] terms merely limits their use in the context of telephone-based promotion and advertising. Competitors are still frce to use the generic words or terms in their advertising or otherwise, so long as the senior user's alpha-numeric telephone number is protected.").

180. 967 F.2d 852 (3d Cir. 1992); see also Cytanovich Reading Ctr. v. Reading Gante, 162 Cal. App. 3d 107, 112 (1984) (denying protection to generic mnenionic 321-READ because "[d]ue to the common use of the word 'read' in virtually all contexts and due to the lack of authority holding its use as a telephone number creates a special right, we conclude that neither the number itself nor suffix method, nor Cytanovich's use of same, can be deemed to constitute a trademark or service mark."). The PTO agrees with the Third Circuit's position. Examining attorneys deny registration to telephone mnemonics that incorporate generic terms or descriptive words that lack secondary meaning. See 1 MCCARTHY, supra note $47, \S 7: 13$; Patent and Trademark Office, Trademark Manual of Examining Procedure (TMEP) § 1209.01(b)(12) (2d ed. rev. 1, 1997) [hereinafter TMEP].

181. Dranoff-Perlstein, 967 F.2d at 859. 
promoted his telephone number, INJURY-9. The Third Circuit found that "injury" is a generic term with no common alternatives, but remanded for consideration of secondary meaning and likelihood of confusion. ${ }^{182}$ Since the addition of a suffix or a prefix does not alter a term's generic nature, the court said, infringement would have to be based on a likelihood of confusion between the suffixes " 1 " and " 9 ". 183

\section{The Geographic Limitations Issue}

Traditional trademark law allows more than one business in noncompeting industries to own nonexclusive trademark rights in a mark. ${ }^{184}$ In addition, companies and individuals can maintain concurrent use of identical marks im specific geographic areas by showing priority of use in that region. ${ }^{185}$ In the context of telephone mnemonics, only one business may use a number at any one time. However, some courts have taken advantage of telecommunications technology to carve out telephonic areas of exclusive use. ${ }^{186}$

For example, in Dial-A-Mattress, the court affirmed a preliminary injunction ordering a junior user to notify the carrier not to connect any calls to 800-MATTRES(S) from various New York area codes, where the senior user had established secondary meaning. ${ }^{187}$ Similarly, in Murrin v. Midco Communications, Inc. ${ }^{188}$ the court enjoined a senior user with common law rights in the New York City metropolitan area from using or advertising 800-LAWYERS outside the area of prior use in any manner that would infringe a junior user's registered,

182. See id. at 860,862 .

183. See id. at 861 (quoting 2-3 McCARTHY, supra note 47 , §§ 12:12, 23:15).

184. See supra Seetion II.A.2.

185. See id.

186. In contrast, courts are unable to carve out areas of exclusive use for Internet domain names because cyberspaee lacks geographic boundaries. "By simply setting up, and posting information at, a website ... one has done everything necessary to reach the global internet audience." Maritz, lnc. v. Cybergold, Inc., 947 F. Supp. 1328, 1332 (E.D. Mo. 1996) ("[A] telephone number still requires a print media to advertise that telephone number."). See also Inset Sys., Inc. v. Instruction Set, Inc., 937 F. Supp. 161, 165 (D. Conn. 1996) ("The Internet as well as toll-free numbers are designed to communicate with people and their businesses in every state."). While the release of new domain name registries may allow busmesses in non-coinpeting industries to use the same domain name in different registries, the nature of the Internet has thus far precluded such concurrent use. See American Network, Inc. v. Access Am./Connect Atlanta, Inc., 975 F. Supp. 494, 496 (S.D.N.Y. 1997) ("II]t is not clear... that defendant could publish a page on its Web site in a way as to make it accessible to users in some jurisdictions but not others...."). Instead, the first legitimate user to register receives use of a domain name. See Weiswasser, supra note 20, at 170 ("[W] hen two companies use the same trademark, "the first to register may be able to retain the domain name, even if the other party has been using the mark on which it is based for many years."') (quoting James W. Moranda \& Christian H. Nadan, Can Trademark Law Regulate the Race to Claim Internet Domain Names?, COMPUTER L., Feb. 1996, at 10, 11).

187. See Dial-A-Mattress Franchise Corp. v. Page, 880 F.2d 675 (2d Cir. 1989).

188. 726 F. Supp. 1195, 1201 (D. Minn. 1989). 
mcontestable service mark "Dial LAWYERS." In Multi-Media Corp., the court ordered the defendants to notify the phone company not to connect any calls to 800-YELLOW BOOK from area codes in the New York metropolitan area and several Florida counties pending the outcome of litigation. ${ }^{189}$ Although all of the above cases involved conflicts between holders of local numbers and toll-free numbers, presumably the same legal analysis and technology could apply to conflicts between users of equivalent or complementary numbers with different SACs. If necessary, a court could determine priority of use and carve out areas of exclusive use for different toll-free numbers and prefixes. However, although courts have the technical ability to create territorial zones of trademark rights for holders of conflicting vanity numbers, the release of new toll-free prefixes and the problems caused by the FCC's firstcome, first-served registration policy demand that the industry and courts consider an alternative registration and dispute settlement process.

\section{III}

Proposal For the Establishment of a NeW Registration AND DisPute SETTLEMENT POLICY FOR

TOLL-Free TelePhone Numbers

As I discussed in Part II, some courts incorporate a recognition of the nature of the telecommumications medium into their trademark analysis of vanity toll-free numbers. However, the case law does not go far enough. The Holiday Inns rule-that a competitor may benefit passively from consumer confusion-is inconsistent with the policy goals underlying trademark law, namely the avoidance of consumer confusion and the prevention of free riding on established goodwill by competitors. This Part discusses the various factors that compel the adoption of a more structured registration and dispute settlement regime for tollfree vamity phone numbers. I propose the establishment of a registration system that embraces ideas from the analogous context of Internet domain names. Also, I recommend the integration of a dispute settlement policy within the PTO's existing framework.

\section{A. Factors Contributing to the Need for a New Registration and Dispute Settlement Policy}

The release of new toll-free telephone prefixes necessitates the establishment of a separate, uniform structure for registration and dispute settlement. The FCC's first-come, first-served policy is madequate to

189. See Multi-Local Media Corp. v. 800 Yellow Book, Inc., 813 F. Supp. 199, 206 (E.D.N.Y. 1993). 
cope with both the increase in the amount of available toll-free numbers, and the level of their use. Nine out of ten people use toll-free phone numbers, cumulatively making approximately thirty-four billion calls each year. ${ }^{190}$ The numbers are used not only by businesses as vanity numbers, but also for personal use, residential use, pagers, messaging devices, pre-paid calling cards, and computerized information lines. ${ }^{191}$ The sheer volume of toll-free numbers and calls, aggravated by the steady introduction of new toll-free SACs, suggests the potential for consumer chaos and a flood of trademark litigation. The rise in the quantity of numbers that are identical except for their prefixes will multiply the probability for consumer confusion and expand opportunities for number brokers.

The FCC should adjust its dispute settlement mechanism to conform to this shift in the toll-free telephone industry. The long-term transaction costs created by the constantly expanding market for tollfree numbers outweigh the initial cost, delay, and administrative burden that may accompany the adoption of my proposed registration and dispute resolution system, which merely expands the capabilities of existing mechanisms. In the long run, businesses have an interest in the implementation of a screening and dispute resolution process because the transaction costs incurred by the present, unstructured approach are many and varied.

The FCC denies a right of first refusal to current holders of tollfree numbers because allowing such a right would automatically deplete the pool of numbers available in newly released toll-free prefixes. ${ }^{192} \mathrm{Un}$ fortunately, the FCC's first-come, first-served policy without a right of first refusal could unfairly rob businesses of enormous investments in advertising and marketing merely because they may not be the first to reserve equivalent and complementary numbers in newly released SACs. A competitor who obtams the use of an equivalent number will collect a large windfall from callers' mistaken assumptions that they will reach the same business by dialing identical vanity numbers in different prefixes. ${ }^{193}$ Likewise, a junior user of a trademark may garner an unjust windfall by reserving a number equivalent to that of a more senior,

190. See Wilcox, supra note 7, at B1; Timothy Wilson, Dial WWW for Service, Web Customer Service Could Spell the End for 800 Numbers, S.F. ExamINER, Aug. 23, 1998, at B5.

191. See Greg Edwards, 877 To Join Toll-Free Prefixes, Richmond Times-Dispatch, Mar. 4, 1998, at C1; Joshi, supra note 30, at A69.

192. The FCC believes that consumers will gradually understand the distinction between the different SACs as new toll-free prefixes are released. See Fourth Report and Order, slipra note 33, I 23.

193. See Glenn S. Richards \& David S. Konczal, FCC Establishes Rules for Toll-Free Vanity Telephone Numbers, 219 N.Y. L.J. 5 (1998) ("Without question, the subscriber assigncd 1-877-COLLECT will reap a substantial windfall from customers' misconceptions that 1-877-COLLECT is the same as [MCI's vanity number] 1-800-COLLECT."). 
established company. My proposal would allow businesses threatened by the loss of goodwill to challenge competitors who reserve equivalent or complementary numbers. In addition, my proposed framework would deter number brokers who try to exploit the first-come, firstserved policy by winning the race to reserve numbers and using their resulting leverage to extort money from large corporations. Although the FCC prohibits number brokering, ${ }^{194}$ the penalties will likely not suspend the practice because businesses may find it easier and less expensive to pay the demands of number brokers than either to suffer the loss of goodwill or to expend money and resources on litigation. ${ }^{195} \mathrm{My}$ proposal would contribute an additional layer of deterrence.

Another factor that suggests the need to establish a new registration and dispute settlement process for toll-free vanity numbers is the potentially high costs of misdials caused by consumer confusion. In addition to a monthly flat fee, telephone carriers charge the holders of toll-free numbers on a per-minute basis for incoming calls. ${ }^{196}$ As a result, the mistakes made by confused callers may produce large telephone bills for companies with vanity numbers or individuals with personal toll-free numbers. The recipient of the bill must either pay the expenses or submit records to their service providers for credit or reimbursement. ${ }^{197}$

Furthermore, the release of new toll-free prefixes is likely to aggravate the potential for litigation. Without a right of first refusal, more businesses will atteinpt to protect their goodwill by obtaining tradeinarks and initiating litigation against competitors who are able to reserve equivalent or complementary numbers under the FCC's first-come, first-served policy. The establishment of formal, FCC procedures that screen registrations and resolve disputes would forestall the filing of lawsuits without wholly foreclosing the option of seeking relief in court. Moreover, a registration and technically specialized dispute settlement process would expedite the resolution of conflicts for companies, especially those that are interested in immediately using a toll-free number.

Finally, although the establishment of a FCC-sponsored registration and dispute settlement policy would require the expenditure of public funds, the cost would be mininal because existing mechanisms could siniply be expanded. Furthermore, the total ainount, in the long run,

194. See Second Report and Order, supra note 15 , IJ 38, 42.

195. See Maney, supra note 3, at B2 (explaining that MCI allegedly paid six figures to a number broker to obtain 800-COLLECT).

196. See Second Report and Order, supra note 15, I74; Oldham, supra note 19, at D4.

197. See Second Report and Order, supra note 15, I 74; David Hayes, Wrong Number! Frustrated Customers Are Inundated by Calls - And Bills - After Being 'Slammed' An Unauthorized Switch in Service, Confusion of Numbers Lead to Chaos, Kansas CiTY STAR, Feb. 18, 1998, at B1 (describing a 26-page phone bill charged to the involuntary recipient of a personal toll-free number after callers misdialed the technical support line for America Online). 
would fall below the high transaction costs associated with misdials, litigation, number brokering, and injuries to goodwill. The public has an interest in avoiding the costs that result from consumer confusion. Certainly, the administrative and economic burden prompted by the adoption of a registration and dispute settlement policy would be less onerous for toll-free phone numbers than for Internet domain names because vanity phone numbers are a domestic issue, not an international one, thereby allowing any new system to fold into the existing structure of the PTO.

\section{B. Registration and Dispute Settlement on the Internet}

Because of the parallels between vanity toll-free numbers and Internet domain names, it is helpful to look to the dispute settlement procedures for Internet domain names as a template for similar procedures in the context of vanity phone numbers. Although NSI's contract with the government expired on September 30, 1998, NSI's policies will continue to govern the registration of Internet domain names until the Commerce Department and Internet leaders create a nonprofit corporation that will gradually assume oversight of the domain name system. ${ }^{198}$

Under NSI's first-come, first-served on-line registration process, a registrar can verify the availability of domain names in seconds and suggest available options for applicants who enter keywords into the system. ${ }^{199}$ NSI requires registrants to certify the truth of all statements in their application and warrant that, to their knowledge, the domain name "does not interfere with or infringe upon the rights of any third party," and "that the applicant is not seeking to use the domain name for any unlawful purpose." ${ }^{200}$ Thus, under NSI policy, the applicant bears the responsibility for not infringing "the rights of any third party with respect to trademark, service mark, trade name, company name or any other intellectual property right." 201 NSI expressly refuses to "determine the legality of the domain name registration, or otherwise evaluate whether that registration or use may infringe upon the rights of a third party."202 Also, NSI maintains the right to "revoke, suspend, transfer, or otherwise modify a domain name registration...."203

198. See Simons \& Simpson, supra note 54, at B8. Although NSI is a private entity, it has such a dominant influence in the field that its rules have become "powerful quasi-statutes." Seyamack Kouretchian, Revised Rules Govern Domain-Name Disputes: To Adequately Preserve Their Rights, New Registrants Should File for Trademark Protection, NAT'L L.J., Oct. 28, 1996, at C20.

199. See WorldNIC, Domain Name Registration (visited Mar. 24, 1998) <http:/l reg2.worldnic.com/SERVICES/>.

200. Panavision Int'1, L.P. v. Toeppen, 945 F. Supp. 1296, 1299 (C.D. Cal. 1997).

201. Id.

202. Domain Name Dispute Policy, supra note 61, I 2.

203. Id. I 7 . 
Registrants must indemnify NSI and the National Science Foundation from any claim arising out of registration or use of the domain name. ${ }^{204}$

If a third party believes that a domain name infringes its intellectual property rights, that party can initiate NSI's dispute procedures by notifying NSI of its allegations. The complainant must supply evidence of a valid trademark registration that is both identical to a second-level domain name and registered on the Principal Register of the United States or the equivalent registry of a foreign country. ${ }^{205}$ In addition, NSI must receive a copy of a written, prior notice to the domain name holder of the alleged violation and the factual and legal bases for the assertion. ${ }^{206}$ If the domain name holder registered the domain name prior to the date that the complainant's trademark became effective, NSI will not intervene. However, if the registrant created the domain name after the effective date of the trademark registration, NSI will direct the registrant to provide proof of ownership of a registered trademark or service mark. ${ }^{207}$ After receiving a dispute notification letter froin NSI, the holder has thirty days to select one of four options, or NSI will place the domain name on "Hold," in other words, make it unavailable for use. The holder's four options are to

(1) Provide the documentation [showing proof of ownership of a registered tradeinark or service mark], (2) Relinquish the domam name and transfer it to the complainant, (3) Register a new and different domain name [with the assistance of NSI after submitting a Registration Agreement requesting a new domain name], or (4) File a civil action and provide a copy of a file-stamped complaint .... ${ }^{208}$

If either party files a civil suit related to the registration and use of the domain name in any competent court, domestic or imternational, NSI "will mamtain the status quo ante of the domain name record pending a temporary or final decision of the court" and "deposit control of the domain name into the registry of the court ...."209 In other words, if the domain name does not have a Hold status, it will not be put on Hold, and if it is already on Hold, it will remain in Hold status. NSI can reactivate a domain name placed on Hold to conform to the order of a court or arbitrator, a settleinent agreement, or the request of the coniplamant.

204. See id. 16.

205. See id. I 8(a).

206. See id. I 8.

207. See id. IJ 9(b)-(c).

208. Id. I 9(e).

209. Id. 


\section{Criticisms of NSI's Current Policies}

Criticisms of NSI and its policies are abundant and suggest implications for the context of toll-free phone numbers. For example, a firstcome, first-served registration policy, as in the context of toll-free phone numbers, may create trademark disputes by ignoring the possibility that the first registrant lacks a valid trademark claim or that others have equally legitimate claims. ${ }^{210}$ NSI has responded to this potential problem by instituting a certification provision for registrants and establishing a dispute settlement policy. ${ }^{211}$ However, if a third party challenges a domain name holder's registration, NSI's rules require the holder to produce evidence of domestic or foreign trademark registration on the Principal Register. ${ }^{212}$ Consequently, parties with legitimate state or common law rights receive no protection on the Internet and may lose domain names to junior users. ${ }^{213}$ Critics argue that mere registration is no longer sufficient to operate on the Internet. Instead, a user must perform trademark searches and registration. ${ }^{214}$ This result conflicts with the express intent of the Lanham Act, which recognizes trademark protection for unregistered marks and permits concurrent use of identical marks by non-competitors and those with common law rights. ${ }^{215}$

Moreover, NSI's rules only apply to second level domain names that are identical to registered trademarks. The policies do not bar identical domain names with different top level domains. Thus, under NS1 rules, Columbia University may register "columbia.net" if it owns a registered mark, even if Columbia House already operates "columbia.com." Also, NSI's policy does not prohibit confusingly similar domain names, such as "wire.com" and "wired.com" or "caplan.com" and "kaplan.com."216 The issue of confusingly similar toll-free telephone numbers and domain names implicates the difficulties of drawing telephonic and cyberspace boundaries. Courts rarely create telephonic areas of exclusive use for similar or non-competing marks and find it impossible to draw such lines over the Internet. ${ }^{217}$

\footnotetext{
210. See Sterling, supra note 50 , at 746-47.

211. See Domain Name Policy Dispute, supra note 61, $992,8-9$.

212. See id. I 8(a).

213. See Lockheed Martin, Corp. v. Network Solutions, Inc., 985 F. Supp. 949, 953 (N.D. Cal. 1997); Weiswasser, supra note 20, at 175.

214. See Kouretchian, supra note 198, at C20.

215. See 15 U.S.C. \& 1125(a).

216. See Weiswasser, supra note 20 , at 176.

217. See id. at 169-70 ("In cyberspace ... one domain name cannot be issued to two people or companies, no matter how distinct their products or inarkets, because the Internet represents, simply, one large geographic area. There are no realistic boundaries in cyberspace that allow two companies with the same name to coexist peacefully and profitably.").
} 


\section{Proposals for Future Governance of the Internet}

With the expiration of NSI's contract with the federal government, industry observers have advocated changes to the system of Internet governance. Two major proposals have emerged. First, the IAHC and CORE recommended substantive guidelines for the administration of domain name disputes. Second, the Department of Commerce released a policy statement, called the White Paper, which promotes a U.S.-based privatization of domain name system management. ${ }^{218}$

\section{a. IAHC's gTLD-MoU and CORE's CORE-MoU}

On May 1,1997, approximately eighty private and public entities from around the world, including Internet Service Providers, user groups, the Internet Assigned Numbers Authority (IANA), and the Internet Society (ISOC), signed the Generic Top LeveI Domain Memorandum of Understanding (gTLD-MoU), which grew out of the IAHC's Final Report. ${ }^{219}$ The gTLD-MoU created the international Policy Oversight Committee (POC) and CORE, whose members signed their own Memorandum of Understanding (CORE-MoU).

The European-based POC and CORE both proposed rapid movement to private, for-profit registrars, organized under CORE, that would assign SLDs on "a fair-use, first-come, first-served basis."220 In addition, up to seven new registries from four global regions would be added immediately, with twenty to thirty more registrars added each year. ${ }^{221}$ POC and CORE would store all domain names in an international trademark and domain name registry, possibly administered by a World Intellectual Property Organization (WIPO) agency. The potential result of such new registries is an increase in litigation. Just as businesses with 800 vanity numbers may challenge competitors using identical numbers with new, different prefixes, companies with donrain names in the ".com" TLD may litigate over consumer confusion caused by

218. See Management of Internet Names and Addresses, 63 Fed. Reg. 31,741 (1998) [hereinafter White Paper].

219. See Policy Oversight Committee, Comments of Policy Oversight Comm. on Technical Management of Internet Domain Names (released Mar. 23, 1998) <http://www.gtld-mou.org/docs/ poc-gp-response.htm> ("As of March 15, 1998, this has increased to over 200 signatory organizations .....) [hereinafter Comments of Policy Oversight Comm.].

220. Memorandum of Understanding on the Generic Top Level Domain Name Space of the Internet Domain Name System, § 7(e) (signed May 1, 1997) <http://www.gtld-mou.org/gTLDMoU.html> [hereinafter $g T L D-M o U]$.

221. See Klein, supra note 55, at B11 ("The seven new gTLDs would be: '.firm' for businesses, 'store' for offering goods for sale, '.web' for activities related to the World Wide Web, '.arts' for cultural and entertainment entities, '.rec' for recreation and entertainment, '.info' for information services and '.nom' for personal names for individuals."). 
equivalent or complementary domain names in TLDs like ".firm" or ".store." 222

Under the POC and CORE guidelines, third parties could challenge the use of SLDs by domain naine holders and request either that the domain name be transferred to the complainant, or that the domain name be excluded from one or inore registries. ${ }^{223}$ These guidelines provide broader protection to tradeinarks than the NSI rules because POC and CORE recognize that closely similar, as well as identical, domain names can cause consumer confusion and parties therefore should have the ability to transfer or exclude them. ${ }^{224}$ Closely similar domain names include those that are identical but have different punctuation, like "holidayinns.com" and "holiday-inns.com," and those that are identical but have minor changes, such as misspellings, homonyms, or character replacement. For example, "hollydayinns" and "h0lidayinns" would constitute closely similar SLDs. Moreover, the guidelines treat translations and clearly misleading SLDs as closely similar, including "phonetic variations, for example, 'foryou.firm' v. '4u.firm', etc."225

\section{b. The Commerce Department's White Paper}

On June 5, 1998, the Department of Commerce responded to the POC and CORE suggestions by releasing its so-called White Paper on the proposed management of Internet doinain naines. ${ }^{226}$ The White

222. See id.

223. See Substantive Guidelines, supra note 20 , at Part III.A. The POC and CORE proposals would require applicants to agree that any dispute with a third party over the domain name may be submitted to an Administrative Domain Name Challenge Panel ("ACP"), on-line mediation, or on-line arbitration in accordance with rules and procedures prepared by the WIPO Arbitration and Mediation Center. See Memorandum of Understanding for the Internet Council of Registrars, art. 7(a), (b) (visited March 25, 1998) <http://www.gtld-mou.org/docs/core-mou.htm> [hereinafter CORE$M o U]$. ACPs would serve an administrative, not legal, function, with jurisdiction over SLDs. See Substantive Guidelines, supra note 20, at Part I.C. ACPs would not be able to assert jurisdiction over persons, affeet the interpretation and enforcement of national or regional intellectual property laws, or preclude any party's ability to obtain a de novo hearing before a national or regional court. See id. at Parts I.C, V.D.

224. POC and CORE's proposed policy is as follows:

[A] second-level domain in any of the CORE-gTLDs whieh is identical or closely similar to an alphanumeric string that ... is deened to be internationally known, and for which demonstrable intellectual property rights exist, may be held or used only by, or with the authorization of, the owner .... Appropriate consideration shall be given to possible use $\ldots$. by a third party that ... is deemed to have sufficient rights.

CORE-MoU, supra note 223, at Art. 2(f). Broad exclusion froun nultiple CORE-gTLDs may only occur in "exceptional cases" if a trademark is globally known, in other words, trademark registration is effective in seventy-five or more countries. See Substantive Guidelines, supra note 20, at Part IV.D.

225. Id. at Part IV.C.

226. See White Paper, supra note 218. The White Paper revises the Green Paper, which was the Department of Commerce's original response to the IAHC and CORE proposals. See Improvement of Technical Management of Internet Names and Addresses, 63 Fed. Reg. 8,826 (1998) [hereinafter Green Paper]. 
Paper is a general policy statement that recommends the creation of a U.S.-based, private, non-profit corporation, that would assume all functions, databases, and the primary root-server system from NSI. The corporation would have a board of directors whose members would represent global diversity. The new corporation would establish procompetition, minimum criteria for registrars to obtain domain names, and would retain discretion to decide the number of new, additional domain name registries. ${ }^{227}$

The White Paper emphasized the need for access to searchable databases of registered domain names. ${ }^{228}$ This aspect of the proposal would have the beneficial effect of forestalling litigation because registrants could search for potential conflicts before applying for a domain name. Also, trademark holders who suspect infringement could obtain data about the allegedly infringing domain name, such as contact information and the date of registration. ${ }^{229}$

The White Paper also proposed policies to address trademark issues. First, at the time of registration, applicants would agree to litigate infringement disputes in a court located in the jurisdiction of the registry, registry database, or "A" root servers. Second, registrants would agree to resolve any cyberpiracy and cybersquatting conflicts through a binding alternative dispute resolution (ADR) system. Third, registrants would agree to follow any new policies that would remove certain famous trademarks from the pool of available domain names, except for use by the trademark owner. ${ }^{230}$

After the release of the White Paper, the Commerce Department reached a new agreement with NSI that seeks to build a more competitive system of registration for domain names. ${ }^{231}$ The agreement, which the parties completed after NSI's exclusive contract expired, will permit other companies to register domain names and will provide the government with access to NSI's technical data. ${ }^{232}$ NSI's monopoly over domain name registration and policies will continue until the Commerce Department and other Internet groups create a nonprofit corporation, like that proposed in the White Paper, which will assume oversight of the system. ${ }^{233}$

227. See White Paper, supra note 218, at 31,745. The White Paper abandoned the Green Paper's proposal to add five new gTLDs. See id.

228. See White Paper, supra note 218 , at 31,750 .

229. See id.

230. See id. at 31,751 .

231. See Simons \& Simpson, supra note 54 , at B8.

232. See id.

233. See id. NSI and IANA issued a joint proposal regarding the structure and functions of the new nonprofit corporation. See Karen Kaplan, Pact Reached on Internet Control Technology: Plan Is Finalized Just Weeks Before Termination of The Government's Role in Operating The Computer Network, L.A. TimES, Sept. 18, 1998, at D1. 


\section{Proposed System for the Registration and Dispute Settlement of Toll-Free Numbers}

In order to address the problems of consumer confusion that are caused by the FCC's first-come, first-served policy but only inadequately resolved by the courts, the FCC should adopt a toll-free telephone number registration system that incorporates features from NSI's current domain name policy and the CORE and White Paper proposals. Also, the FCC should integrate a dispute settlement process for trademark conflicts involving toll-free numbers within the framework of the PTO's existing challenge procedures.

\section{Registration}

The FCC should adhere to its first-come, first-served registration policy for toll-free telephone numbers, but should draw parallels from the analogous context of Internet domain names. Specifically, the FCC should expand its current database system and augment its certification requirements to resemble more closely those aspects of NSI's current policy and the CORE and White Paper proposals.

Although the FCC's first-come, first-served registration policy contributes to consumer confusion because it allows junior users to register numbers that are equivalent and complementary to established mnemonics, an alternate framework based on a right of first refusal would be an impractical alternative. If holders of existing numbers could exercise a right of first refusal for numbers with new prefixes, every pool of newly released numbers would automatically be depleted, thereby defeating the purpose of making new numbers available. ${ }^{234} \mathrm{In}$ stead, the FCC should expand its database and certification requirements to limit conflicts caused by the first-come, first-served policy. Any senior users who seek to protect their goodwill but are unable to reserve an equivalent or complementary number in a new prefix could enter the FCC's dispute settlement process.

Expansion of the technical capabilities of the SMS database, from mere storage of information to the ability to screen across every tollfree prefix, would reduce the potential for consumer confusion by forestalling the registration of conflicting mnemonics. Like the searchable domain name database proposed by the Commerce Department, ${ }^{235}$ the SMS database could enable both RespOrgs and individual subscribers to check the availability of a toll-free number and the existence of identical and similar numbers with different prefixes. The applicant would

234. See supra Section I.D.1.

235. See White Paper, supra note 218. 
then be alerted as to potential trademark conflicts. ${ }^{236}$ Also, the database would provide information regarding the identification and mailing address of the holder of a conflicting number, as well as the dates of registration and any opposition filings. ${ }^{237} \mathrm{~A}$ registrant who suspects infringement can then initiate challenge proceedings at the PTO or file suit in federal district court.

Second, the FCC should extend its current certification requirement, which deters warehousing by obligating RespOrgs to warrant that a specific subscriber has requested the number for service. ${ }^{238}$ The FCC would forestall trademark conflicts by including a clause similar to one in NSI's registration application, whereby applicants certify that, to their knowledge, the toll-free telephone number will not interfere with or infringe the intellectual property rights of third parties. ${ }^{239}$ Such a provision would deter businesses from attempting to free ride on competitors' goodwill. To deter number brokers, the FCC would require registrants to pledge that the number will not be used for any unlawful purpose. ${ }^{240}$ The FCC should impose penalties for violations of any certification requirement. Those penalties should include forfeiture of the number at issue, termination of toll-free service, and liability for false statements. ${ }^{241}$

Modeling the FCC's database and certification requirements on policies and proposals from the analogous context of Internet domain names would not only limit conflicts caused by the first-come, firstserved policy, but also avoid excessive expense and administrative burden. Merely extending existing mechanisms would neither create high costs nor add to the agency's bureaucracy.

\section{Legal Standards}

Under this proposed dispute settlement policy, the PTO would apply the traditional likelihood of confusion factors to determine proceedings between conflicting mnemonics. In addition, the PTO would incorporate into its analysis considerations of the unique nature of the telecommunications medium and the toll-free vanity telephone industry.

For example, when the PTO considers the likelihood of confusion between vanity numbers, it should deny trademark protection both to

236. A searchable database would serve as a speedy alternative to pre-registration publication of toll-free numbers and their assoeiated mnemonics in an official journal. See, e.g., TMEP, supra note $180, \S 1502$ (explaining that after a determination by a trademark exaniner that a trademark is registrable, the mark is published in the Official Gazette of the Patent and Trademark Office for opposition).

237. See id.

238. Cf. Second Report and Order, supra note 15, I 25 (explaining that reservation of a toll-free number merely certifies that there is an identified subscriber who will use the number).

239. See Domain Name Dispute Policy, supra note 61.

240. See id.

241. See Second Report and Order, supra note $15,9 g 29,42$. 
equivalent mnemonics with different prefixes and complementary and confusingly similar vanity numbers. In a manner analogous to the CORE proposal, which bars closely similar and identical domain names, ${ }^{242}$ the PTO should invalidate even minor differences in the mnemonics, such as misspellings, homonyms, phonetic variations, or similar character substitutions, if the result is an impermissible level of confusing similarity. ${ }^{243}$ For instance, "GO-U-HALL" and "G[zero]-UHAUL" would constitute confusingly similar vanity numbers.

One aspect of the toll-free vanity telephone industry that the PTO should incorporate into its analysis of conflicting mnemonics is a recognition of passive exploitation of equivalent and complementary numbers. Contrary to the holding in Holiday Inns, Inc. v. 800 Reservation, Inc. ${ }^{244}$ the PTO should protect mnemonics from passive, as well as active, exploitation because such use can cause consumer confusion. Use of a telephone number to transact business should constitute sufficient use in commerce to meet the requirements of the Lanham Act. In particular, the PTO should not permit companies deliberately to reserve the equivalent or complementary numbers of competitors and free ride on their goodwill, especially if consumer confusion results. Such conduct "seems to be a clear violation of the spirit, if not the letter, of the Lanham Act," ${ }^{245}$ which attempts to prevent consumer confusion as to the source of goods and services and to protect the business community's interest in maintaining goodwill investments without undue encroachment on competition.

Second, the PTO should follow the Second Circuit's opinion in Dial-A-Mattress Franchise Corp. v. Page, ${ }^{246}$ which recognized that the traditional rules for genericness are insufficient in the context of tollfree vanity numbers. ${ }^{247}$ By adhering to Dial-A-Mattress, the PTO would merely restrict parties from using generic terms in areas of advertising other than the identification of the relevant telephone number, thereby avoiding the anti-competitive appropriation of generic terms while preventing the defendant from causing consumer confusion and free riding on the plaintiff's goodwill. ${ }^{248}$

242. See CORE-MoU, supra note 223, at art. 2(f). In contrast, NSI's rules only apply to SLDs that are identical to registered marks. NSI does not bar identical domain names with different TLDs. See Weiswasser, supra note 20 , at 176.

243. See, e.g., Substantive Guidelines, supra note 20, at Part IV.C (proposing a parallel standard in the Internet domain name context).

244. 86 F.3d 619 (6th Cir. 1996); see supra Section II.B.2.

245. Holiday Inns, 838 F. Supp. 1247, 1255 (E.D. Tenn. 1993), rev'd, 86 F.3d 619 (6th Cir.

1996).

246. 880 F.2d 675 (2d Cir. 1989); see supra Section II.B.3.

247. The PTO currently follows the Third Circuit by refusing to grant trademark protection to mnemonics that incorporate generic terms. See TMEP, supra note 180, § 1209.01(b)(12).

248. See id.; supra Section II.B.3. 
Third, unlike NSI, which requires evidence of registration of a trademark on the primary federal or foreign registry, ${ }^{249}$ the PTO should recognize state common law trademark rights. Because telecommunications technology allows the creation of zones of exclusive use, the PTO can apply a traditional priority of rights analysis. The PTO can then provide trademark protection to junior users in remote geographic areas by ordering the parties to notify their carriers not to connect calls from the relevant area codes. ${ }^{250}$ Adoption of such a policy would allow concurrent use by remote and non-competing users, while still avoiding consumer confusion.

In sum, once the holder of a vanity nunber enters the PTO's challenge process, the PTO should not only apply traditional likelihood of confusion factors, but also incorporate rules that recognize issues unique to the toll-free vanity phone numbers industry. Thus, the PTO should follow the Holiday Inns and Dial-A-Mattress holdings and recognize common law trademark rights by creating areas of exclusive use. ${ }^{251}$

\section{Dispute Resolution}

Additionally, the FCC should encourage parties to utilize the PTO's existing framework of trademark challenge procedures to resolve disputes involving toll-free numbers. Just as expansion of the FCC's database and certification requirements would avoid excessive expense and administrative burden, the use of the PTO's existing structure for conflicts concerning toll-free numbers would result in little cost. In fact, resolving vanity number disputes through PTO procedures may eventually reduce transaction costs because the proceedings will fully settle many conflicts, thereby forestalling litigation. Moreover, utilizing the technical expertise of an admimistrative agency may be faster than litigation and produce reliable, uniform decisions.

Parties who choose to enter the PTO system would either submit an application for trademark registration of a vanity mnemonic to a Trademark Examining Attorney, ${ }^{252}$ or challenge the registration of an allegedly infringing mnemonic in a proceeding before the Trademark Trial and Appeal Board (TTAB). Thus, registrants who already possess trademark rights would initiate an opposition, cancellation, concurrent

249. See Domain Name Dispute Policy, supra note 61, I 8(a); supra Section III.B.

250. For examples of courts creating territorial zones of trademark rights for holders of conflicting vanity numbers, see Dial-A-Mattress Franchise Corp. v. Page, 880 F.2d 675 (2d Cir. 1989); Multi-Local Media Corp. v. 800 Yellow Book Inc., 813 F. Supp. 199, 206 (E.D.N.Y. 1993).

251. See supra Section II.B.4.

252. See TMEP, supra note $181, \S 1105$. 
use, or interference proceeding before the TTAB. ${ }^{253}$ The same PTO procedures would apply to number brokers as competitors, because both threaten to cause consumer confusion. The burden of proof would rest with the junior user, in other words, the user with the latest filing date. ${ }^{254}$

The TTAB is an administrative tribunal that lacks the power to decide infringement or unfair competition claims, but may determine the right to register trademarks. ${ }^{255}$ As a result, a toll-free number subscriber may challenge the validity of a conflicting registration in two ways: (1) by filing a proceeding before the TTAB; or (2) by filing a civil action for infringement or unfair competition in a federal district court. ${ }^{256}$ Again, registrants will have an incentive to use the PTO procedures because the formal dispute resolution structure and the expertise of the TTAB will result in fast, reliable, uniform decisions. For similar reasons, applicants will also follow the PTO's procedures to appeal the decisions of the TTAB. ${ }^{257}$

\section{a. Opposition Proceedings}

An opposition proceeding allows a party to block the issuance of a trademark registration if the registration will "damage" the party. ${ }^{258} \ln$ other words, the party filing the opposition must have a personal interest in the outcome of the decision exceeding that of the general public. ${ }^{259}$ Opposition proceedings begin after both a Trademark Examining Attorney deems the contested mark registrable and the mark is published in the PTO's Official Gazette, but before issuance of the trademark. ${ }^{260}$ In the context of toll-free numbers, a party who wants to prevent registration of a potentially damaging vanity number may institute an opposition proceeding while the registration is still pending. For instance, the holder of a registered trademark can oppose the registration of an equivalent or complementary number by a number broker. The PTO would provide relief by suppressing the contested mark's

253. See TBMP, supra note $21, \S 102.02$ (deseribing the four types of TBMP proceedings). The Department of Agriculture's Plant Variety Protection Office has a structure analogous to the PTO for the issuance of patent-like Certificates of Protection for new, distinct, uniform, and stable varieties of sexually reproduced or tuber propagated plants. See Plant Variety Protection Act, 7 U.S.C. § 2402(a) (1994).

254. See TBMP, supra note $21, \S 301$ (quoting 37 C.F.R. $2.116(b)$, which designates the party initiating an opposition or cancellation proceeding and the junior user in interference and concurrent use proceedings as the plaintiff).

255. See id. § 102.01 .

256. See 37 C.F.R. 2.145; TBMP, supra note $21, \S 901.01$.

257. See TBMP, supra note 21 , at ch. 900 .

258. 15 U.S.C. \$ 1063(a) (1994); TBMP, supra note 21, § 201.

259. See TBMP, supra note $21, \S 303.03$.

260. See 15 U.S.C. § 1063(b) (1994); TBMP, supra note 21, §\$ 201, 307. 
registration and use or, possibly, transferring the toll-free number to the filer.

\section{b. Cancellation Proceedings}

In a cancellation proceeding, the plaintiff attempts to cancel an existing trademark registration. ${ }^{261}$ Unlike opposition proceedings, cancellation proceedings occur after the issuance of a contested mark, but must be filed within five years of publication in the Official Gazette. ${ }^{262}$ Under this proposed dispute settlement process for toll-free numbers, an applicant who discovers that another party has registered a mnemonic and is using it in a damaging manner may file a cancellation proceeding. Within these mechanisms, the TTAB may then cancel the registration of the contested number and either disconnect it or transfer it to the plaintiff.

\section{c. Concurrent Use Proceedings}

In a concurrent use proceeding, one or more applicants seek to establish concurrent trademark registrations, which entitle the holders to conditional or limited rights. ${ }^{263}$ Thus, if the likelihood of consumer confusion, mistake, or deception is low, a concurrent use proceeding can impose geographic limitations on identical or similar trademarks by carving out areas of exclusive but concurrent use for multiple registrants who have equally legitimate claims in different geographic regions. ${ }^{264}$ Conflicts involving toll-free telephone mnemonics should utilize concurrent use proceedings, because telephone carriers have the ability to create areas of exclusive use. ${ }^{265}$ The TTAB could order a carrier not to connect calls from specific area codes to a toll-free telephone number. Concurrent use proceedings would provide relief by allowing the simultaneous use of the same or similar mnemonic by remote businesses in non-competing industries or companies that have shown priority of use in particular, sufficiently distant regions. A concurrent use proceeding could also order the use of gateway intercepts if the parties have legitimate claims to the same or similar mnemonic. ${ }^{266}$

261. See TBMP, supra note $21, \S 308.02$.

262. See id.

263. See id. $\$ 1101.01$.

264. See id.

265. See supra Section II.B.4.; see also Dial-A-Mattress Franchise Corp. v. Page, 888 F.2d 675, 677 (2d Cir. 1989) (affirming an order to notify the telephone carrier not to connect calls to defendant from certain New York area codes); Multi-Local Media Corp. v. 800 Yellow Book Inc., 813 F. Supp. I99, 206 (E.D.N.Y. 1993) (ordering defendant to notify the phone company not to connect calls from certain area codes in New York and Florida).

266. See Notice of Proposed Rulemaking, supra note 1, I 46; supra Section I.D.4; cf. Second Report and Order, supra note 15,975 (rejecting the idea that the FCC require gateway intercepts 


\section{d. Interference Proceedings}

In an interference proceeding, the PTO either assigns a trademark registration to one of two applicants for a single registration, or assigns trademark rights between an applicant and the holder of an existing registration. ${ }^{267}$ Interferences are only permitted in extraordinary circumstances, when, absent the proceeding, a party will be unduly prejudiced by a confusingly similar mark. Recourse to an opposition or cancellation proceeding eradicates any undue prejudice. ${ }^{268}$ In the context of tollfree telephone numbers, the PTO would determine priority of use between conflicting applications and decide whether the mnemonics are confusingly similar. ${ }^{269}$ The parties will seek disconnection or transfer of the contested number or, eventually, cancel the registration.

\section{e. Appeal Process}

Finally, an applicant for a trademark registration may make an ex parte appeal to the TTAB from a final decision of a Trademark Examining Attorney who has refused to issue a registration. ${ }^{270}$ In addition, any registrant or party to an opposition, cancellation, concurrent use, or interference proceeding may appeal from TTAB decisions by either petitioning for review by the U.S. Court of Appeals for the Federal Circuit (CAFC) or by filing a civil action in a federal district court. ${ }^{271}$ By appealing to the CAFC, a party waives the right to file a civil action, although an adverse party may file a petition to dismiss the appeal and remove the dispute to district court. ${ }^{272}$

\section{CONCLUSION}

As the value and market for toll-free telephone numbers continue to explode, the potential for consumer confusion over complementary vanity numbers will correspondingly increase. The strict application of traditional trademark law inadequately addresses this important phenounenon. In shaping policies for the assigninent and dispute settlement of toll-free vamity phone numbers, the FCC needs to take several crucial, proactive steps.

because an intercept may both be technologically difficult to establish and may "increase post-dial delay, call set-up times, and access times").

267. See 15 U.S.C. $\$ \$ 1066,1068$ (1994); 37 C.F.R. 2.91 (a)-(b).

268. See 37 C.F.R. 2.91(a). Because interferences cannot cancel trademark registrations, a party must file a petition for cancellation before the contested mark will issue to the applicant. See 37 C.F.R. 2.96; TBMP, supra note 21 , at ch. 1002.

269. See 37 C.F.R. 2.96; TBMP, supra note 21, § 1004.

270. See 37 C.F.R. 2.141; TBMP, supra note 21, § 1201.01.

271. See TBMP, supra note $21, \S 901.01$.

272. See id. 
First, instead of simply adopting a narrow trademark law approach to vanity numbers, the agency should take notice of two inportant considerations: (1) the peculiar trademark problems that characterize the telecommunications industry; and (2) the practices and proposals offered in the analogous context of Internet domain names. Second, the FCC should expand the screening capabilities of its registration databases. Third, the FCC should require registrants to certify both that their vanity number will not be used for unlawful purposes, and that it does not infringe the intellectual property rights of third parties. Finally, the FCC should encourage applicants to utilize the PTO's existing framework of trademark challenge and appeal procedures. By adopting procedural devices and legal rules that respond to industry-specific problems, the FCC may stem a potential flood of tradeniark litigation involving conflicting toll-free vanity numbers. More importantly, the FCC would reduce consumer confusion and guide the courts as they struggle with the problems generated by the intersection between traditional trademark law and an evolving medium of telecommunications technology.

Failing to take these steps, and acting reactively rather than proactively, will likely produce several deleterious consequences. It will undermine the core values of trademark law-guarding against consumer confusion and protecting businesses' goodwill from free-riding. It will frustrate the growth of this important, growing market. And lastly, it will mvite litigation, imposing unnecessary costs on parties and overburdening agencies and the courts. 
